FSU-2690-21

Category No. UC-4

MASTER

BULLETIN NO. 21

DIVISION OF BIOLOGY AND MEDICINE, U. S. ATOMIC ENERGY COMMISSION

INSTITUTE OF MOLECULAR BIOPHYSICS

\title{
COPPER PROTEINS AND OXYGEN: CORRELATIONS BETWEEN STRUCTURE AND FUNCTION OF THE COPPER OXIDASES
}

May 15,1965

DEPARTMENT OF CHEMISTRY

FLORIDA STATE UNIVERSITY

TALLAHASSEE, FLORIDA 


\section{DISCLAIMER}

This report was prepared as an account of work sponsored by an agency of the United States Government. Neither the United States Government nor any agency Thereof, nor any of their employees, makes any warranty, express or implied, or assumes any legal liability or responsibility for the accuracy, completeness, or usefulness of any information, apparatus, product, or process disclosed, or represents that its use would not infringe privately owned rights. Reference herein to any specific commercial product, process, or service by trade name, trademark, manufacturer, or otherwise does not necessarily constitute or imply its endorsement, recommendation, or favoring by the United States Government or any agency thereof. The views and opinions of authors expressed herein do not necessarily state or reflect those of the United States Government or any agency thereof. 


\section{DISCLAIMER}

Portions of this document may be illegible in electronic image products. Images are produced from the best available original document. 


\section{LEGAL NOTICE}

This report was prepared as an account of Government sponsored work. Neither the United States, nor the Commission, nor any person acting on behalf of the Commission:

A. Makes any warranty or representation, expressed or implied, with respect to the accuracy, completeness, or usefulness of the information contained in this report, or that the use of dily information, apparatus, method, or process disclosed in this report may not infringe privately owned rights; or

B. Assumes any liabilities with respect to the use of, or for damages resulting from the use of any information, apparatus, method, or process disclosed in this report.

As used in the above, "person acting on behalf of the Commission" includes any employee or contractor of the Commission, or employee of such contractor, to the extent that such employee or contractor of the commission, or employee of such contractor prepares, disseminates, or provides access to, any information pursuant to his employment or contract with the Commission, or his employment with such contractor. 
BULLETIN NO. 21

DIVISION OF BIOLOGY AND MEDICINE, U.S. ATOMIC ENERGY COMMISSION INSTITUTE OF MOLECULAR BIOPHYSICS

COPPER PROTEINS AND OXYGEN: CORRELATIONS BETWEEN STRUCTURE AND FUNCTION OF THE COPPER OXIDASES

May 15, 1965

Department of Chemistry

Florida State University

Tallahassee, Florida. 
Bulletin No. 21, Division of Biology and Medicine,
U. S. Atomic Energy Commission

INSTITUTE OF MOLECULAR BIOPHYSICS and DEPARTMENT OF CHEMISTRY

Florida State University, Tallahassee, Florida

\section{Contents}

Copper Proteins and oxygen: Correlations between Structure and Function of the Copper oxidases* $\neq$

By

Earl. Frieden, Shigemasa Osaki and Hiroshi Kobayashi**

* Supported in part by Grant HE 08344, U. S. Public Health Service, and in part by a contract between the Division of Biology and Medicine, U. S. Atomic Energy Commission and the Florida state University.

\# Preprint from a special issue of The Journal of General Physiology, 1965; also appearing in The Proceedings of the symposium Sponsored by the New York Heart Association.

** Department of Chemistry, Harvard University, Cambridge, Mass. 


\section{ABSTRACT}

A comprehensive survey of the interaction of the copper proteins and oxygen is presented, including a correlation of structure, function and other properties of the known copper oxidases and of hemocyanin. The oxygen reactions of hemocyanin, ceruloplasmin and cytochrome oxidase show half-saturation values far below the other $\mathrm{Cu}$ enzymes. The formation of hydrogen peroxide as a reaction product is associated with the presence of one $\mathrm{Cu}$ atom per oxidase moleculé or catalytic system. Water is the corresponding product of the other $\mathrm{Cu}$ oxidases with four or more $C u$ atoms per molecule, except for monoamine oxidase. Mechanisms for the oxidase action of the . two and four electron transfer $\mathrm{cu}$ oxidases and tyrosinase are proposed. These reactions account for the number, the oxidationreduction potential and the oxidation state of $\mathrm{Cu}$ in the resting enzyme, the cyclical change from $\mathrm{Cu}(\mathrm{II})$ to $\mathrm{Cu}(\mathrm{I})$, the diatomic nature of $\mathrm{O}_{2}$, the sequence of the oxidation and reduction reactions and other salient features. The catalytic reactions involved in the oxidation of ascorbic acid by plant ascorbate oxidase, ceruloplasmin and $C u(I I)$ are compared. Finally the substrate specificity, inhibitory control and the detailed mechanism of the oxidase activity of ceruloplasmin are summarized. 


\section{INTRODUCTION}

We now turn to another group of colorful proteins. Previous authors have discussed the red proteins including hemoglobin and the cytochromes, and the yellow proteins which usually contain some flavin moiety. It is therefore appropriate now to consider the blue proteins which almost invariably contain copper, although it is true that there are several exceptions among the cu proteins such as plasma monoamine oxidase, which is pink, and tyrosinase, which is colorless.

More than twenty well-defined copper proteins have now been recognized, even if the many different tyrosinases and hemocyanins are counted as only one earh. As shown in Table $I$, their distribution is ubiquitous -- from a specific copper protein in plants, plastocyanin, to the widely distributed terminal respiratory enzyme, cytochrome oxidase. They range in molecular weight from $14,6.00 \mathrm{~g}$. for azurin to almost $7,000,000 \mathrm{~g}$. for hemocyanin. Some are essential in their biological function as hemocyanin and cytochrome oxidase, and some play a limited catalytic role as uricase. The most recent addition to this list is the enzyme, dopamine hydroxylase, which is involved in the biosynthesis of norepinephrine. Catalytic activity has not been associated with all of these copper proteins, but in our view the versatility of copper ion as a catalyst makes every copper protein a prime suspect for enzymic activity. So far the catalytic role 
of these copper proteins usually involves oxidation but participation in hydrolytic or transfer reactions should not be excluded. It is unlikely that the identity and function of all the copper proteins have been recognized, ${ }^{l}$ especially in view of the existence of a group of copper proteins for which no obvious physiological function other than transfer or storage can be ascribed at present (Table I).

All but four of the copper proteins in Table I react in some demonstrable way with oxygen and they have played an impressive role in the study of biological oxidation and oxygenation. Hemocyanin is one of the oldest known biological pigments, second only to hemoglobin as an oxygen carrier. No enzyme plays a more vital part in the metabolism of plants and animals than cytochrome oxidase, the almost universal terminal oxidase. Since the role of copper in this enzyme system is still unsettled, we will only note that this enzyme system contains copper ion which appears to change in valence during catalytic activity. The copper enzyme, ascorbate oxidase, is an alternative plant terminal oxidase of some significance. The discovery of the oxygenase. property of many oxidizing enzymes may be credited to the pioneering work of Mason et $\underline{a l}^{2}$ on the copper enzyme, mushroom tyrosinase. It was shown that in the tyrosinase catalyzed oxidation of 3,4-dimethylphenol, the oxygen atom incorporated into the product, 4,5-dimethylcatechol, was derived exclusively from 
molecular oxygen and not from the oxygen of water. This experiment, represented below, was in sharp contrast with the previously widely accepted thesis that oxygen could act only as an ultimate or terminal electron acceptor in biological oxidations. Much of the valuable work on oxygenases and mixed function oxygenases discussed here has evolved from this useful observation.

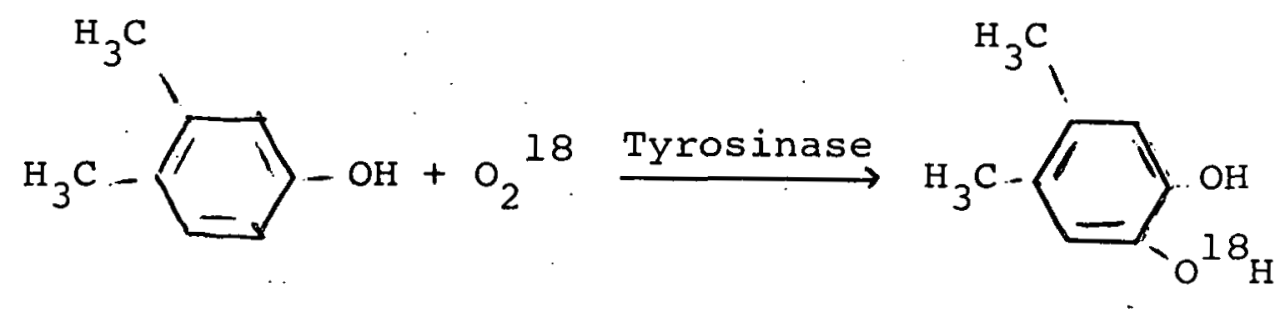

It is at the terminal oxidase stage, presumably cytochrome oxidase. that copper enzymes may be intimately involved in the susceptibility of tissues to radiation damage. According to a proposal of J. Schubert, ${ }^{3}$ radiation produces organic peroxides which oxidize $c u(I)-p r o t e i n s$ to $C u(I I)-p r o t e i n s$. Somehow the Cu(II)-proteins become "fixed" in this oxidation state and thus can no longer react with molecular oxygen, thus impairing respiratory metabolism. The evidence for these ideas is only indirect at present. Schubert reports that protection can be afforded against all types of ionizing radiations, even after exposure, by stabilization of $\mathrm{Cu}(\mathrm{I})$, destruction of the peroxides, or reduction of tissue oxygen. Conversely, Cu(II) stabilizers produce increased sensitivity to radiation. Schubert also notes a positive correlation of the comparative radiation sensitivity 
of animals and their copper contents. However, this correlation does not extend to individual tissues. The most radiosensitive tissues in man are the spleen, pancreas and the cells producing leucocytes which have the least copper and the least cytochrome oxidase.

In a recent discussion of the importance of the copper in cytochrome oxidase for the oxygen utilization of animals and plants, ${ }^{4}$ Chance $^{5}$ noted that the reaction of oxygen with the copper ion of cytochrome oxidase is only one-tenth as fast as the reaction of oxygen with the ferrous hematin of cytochrome oxidase. His doubts about the significance of copper in the intracellular function of cytochrome oxidase are at variance with the views of Griffiths, ${ }^{6}$ who summarized his studies showing "a specific association of copper with cytochrome oxidase which also suggests a role for copper as an active oxidation-reduction catalyst in the reaction catalyzed by cytochrome oxidase."

\section{Oxygen Interaction with Copper Proteins and Enzymes}

Our present knowledge of how oxygen reacts with the copper proteins can only be described as primitive and incomplete. This is due to two main reasons: (1) the lack of appropriate application of a variety of sensitive physical methods for measuring these interactions using fast reaction techniques, and (2) the difficulty in obtaining sufficient quantities of most of the cu-enzymes for adequate study. 
Unique among the Cu-proteins is the interaction of oxygen with hemocyanins which may be written as follows:

$$
\begin{gathered}
\mathrm{Cu}_{2} \text {-protein }+\mathrm{O}_{2} \rightleftharpoons \mathrm{O}_{2}-\mathrm{Cu}_{2} \text {-protein } \\
\begin{array}{c}
\text { Hemocyanin }+\mathrm{O}_{2} \rightleftharpoons \begin{array}{c}
\text { oxy-hemocyanin } \\
\text { (colorless) }
\end{array} \\
\text { (blue) }
\end{array}
\end{gathered}
$$

The rates of these reactions were estimated under physiological conditions in a classical paper by G. A. Millikan in $1933^{7}$ using rapid flow methods developed earlier by Hartridge and Roughton. 8 The dissociation of oxygen from hemocyanin takes 0.1 second to reach completion in the horseshoe crab (Limulus) serum and 0.04 second in spider crab (Maia) serum, as shown in Fig. 1. The dissociation was also accelerated at pH 6.0. While the association process was too rapid to be estimated with any appreciable accuracy, Millikan made an educated guess of a half reaction time of .003 second. These reaction times are reminiscent of the times for the corresponding reactions of hemoglobin. Also, as with hemoglobin, the equilibrium of the hemocyanin-oxygen interaction has been extensively studied 7,9 and will be mentioned later. Met-hemocyanin is reported not to be able to reversibly bind oxygen. 10

The rate of oxygen interaction with the oxidative copper enzymescan only be inferred since oxygen binding is usually a prelude to a rapid oxidation of a reduced form of the enzyme as 
shown in the following reaction sequence:

$$
\begin{aligned}
& \mathrm{Cu}(\mathrm{I})_{4} \text {-Protein }+\mathrm{O}_{2} \rightleftharpoons \mathrm{O}_{2}-\mathrm{Cu}(\mathrm{I})_{4} \text {-Protein } \\
& \mathrm{O}_{2}-\mathrm{Cu}(\mathrm{I})_{4}-\text { Protein }+4 \mathrm{H}^{+} \rightleftharpoons \mathrm{Cu}(\mathrm{II})_{4} \text {-Protein }+2 \mathrm{H}_{2} \mathrm{O}
\end{aligned}
$$

The formation of the $\mathrm{Cu}(\mathrm{II})$-protein can usually be followed without disturbing its state in the protein by determining its electron spin resonance signal. But to our knowledge, rapid flow methods have not been systematically applied to these oxidative reactions. Over $95 \%$ of the reduced $\mathrm{Cu}$ of ascorbate-reduced laccase and ceruloplasmin was reoxidized in less than 0.1 second. ${ }^{11}$ Modification of the oxygen electrode and/or more rapidly responding ESR systems may be needed to study these reactions in more detail. Recently the rate of some of the reactions in which ceruloplasmin is oxidized and reduced have been studied by Broman et al $^{11}$

Quantitative studies of the Interaction of oxygen with Copper proteins

That oxygen binding or oxygen concentration can play a significant role in the rate determining step or steps during the overall reaction involving a Cu-enzyme is suggested by the data in Table II. Second order rate constants for the reaction between oxygen and the cu-protein might be more meaningful but this data is not available except as noted later for ceruloplasmin. In Table II the equilibrium constant for the dissociation, $\mathrm{K}_{\mathrm{m}^{\prime}}$ or half saturation oxygen pressures, have been estimated from scattered 


\section{$-8-$}

data in the literature, usually involving manometric or polarographic methods. For cytochrome oxidase and hemocyanin the oxygen interactions are very intense, indeed. The equilibrium constants for the hemocyanins all fall conveniently under the partial pressure of oxygen in air (158 mm Hg). 7,9 From a variety of data, the half saturation pressure for cytochrome oxidase appears to be within the range of $10^{-6} \mathrm{M}(1-2 \mathrm{~mm} \mathrm{Hg})$. It must be near this if cytochrome oxidase is to function properly in the respiratory chain since it has been estimated that the $\mathrm{pO}_{2}$ of the mitochondrion is no more than one $\mathrm{mm} \mathrm{Hg}$. In 1957, Chance $^{12}$ concluded that the oxygen affinity of the respiratory system is so high that no changes of rate will occur until the oxygen concentration has fallen to about $4 \mu \mathrm{M}(2 \mathrm{~mm} \mathrm{Hg})$ at $25^{\circ}$. The concentrations of oxygen necessary for half the maximum respiration in many intact cellular systems show a similar high oxygen affinity.

In contrast are the data, also included in Table II, for several isolated systems in which $\mathrm{Cu}$ ions play an essential catalytic role. One of the most complete studies has been reported for ascorbate oxidase by Thimann et $\underline{1}^{13}$ and is shown in Fig. 2 . The $\mathrm{K}_{\mathrm{m}}$ is about $16 \% \mathrm{O}_{2}$ or $2.2 \times 10^{-4} \mathrm{M}$. From this and related data it was concluded that the oxygen uptake of potato disks could not be due to a terminal oxidase of relatively low oxygen affinity such as ascorbate oxidase. Cytochrome oxidase is, therefore, a more logical candidate. Since ascorbate oxidase is very 
sensitive to "protection or stabilization" by a variety of substances, it was later observed that the lack of saturation by air could still be observed on a protected enzyme (Fig. 3). ${ }^{14}$ Estimations of the half saturation oxygen concentrations for several other copper ion sensitive systems, listed in Table II, give values in the $10^{-4}$ range, for uricase, and free $\mathrm{Cu}$ (II) catalysis. These data suggest that the protein did not contribute significantly to oxygen binding.

Since we could find no precise data related to tyrosinase and ceruloplasmin, the effect of oxygen on the activity of these enzymes has been studied ${ }^{15}$ with the data shown in Figs. $4 a$ and $4 \mathrm{~b}$ and also in Table II. The $\mathrm{K}_{\mathrm{m}}$ for tyrosinase, $5.5 \times 10^{-5} \mathrm{M}$, is somewhat under the typical copper enzyme listed in Table II. The $\mathrm{K}_{\mathrm{m}}$ for the ceruloplasmin catalyzed oxidation of ascorbate was unexpectedly low, about $4 \times 10^{-6} \mathrm{M}$. Thus, in its apparent affinity for oxygen, ceruloplasmin is comparable to hemocyanin and cytochrome oxidase. Except for the tendency of hemocyanin to aggregate, ceruloplasmin resembles hemocyanin much more closely than cytochrome oxidase in numerous chemical properties. It is even possible that ceruloplasmin represents a vestigial but highly evolved form of hemocyanin. It is of interest that Broman $^{16}$ has suggested that the $\mathrm{cu}$ of ceruloplasmin is the direct precursor of the $\mathrm{Cu}$ of tissue cytochrome oxidase. Regardless of these speculations, it is clear that in what is now known about their relative interactions with oxygen, hemocyanin, 
ceruloplasmin and cytochrome oxidase are substantially different from the other copper proteins or catalytic systems listed in Table II.

Electronic Transitions and the origin of the Blue Color of Copper Complexes and Proteins

With several exceptions (non-oxygenated) all cu-proteins have strong visible absorptions, resulting in blue colors (see Table III), except for monoamine and diamine oxidases which are pink, 17,32 probably due to the presence of a $\mathrm{Cu}($ II) pyridoxalphosphate complex. This lack of absorption in the visible for tyrosinase and hemocyanin (non-oxygenated) is usually associated with the exclusive cuprous state of the metal ion. We now consider the structural basis for the intense blue color of copper proteins and chelates.

Copper complexes with planar and distorted or regular octahedral structures have parity forbidden $d-d$ transitions in the visible region. These molecules have a center of symmetry and cannot obtain the intensity for d-d transition (even-even) by the electric dipole transition selection rule. The observed intensities of octahedral $(\varepsilon=1-150)$ and planar $(\varepsilon=5-250)^{18}$ copper complexes are borrowed from the intensities of either their allowed d-p transition or allowed charge transfer transitions (charge transfer from ligand to metal or the reverse) by a coupling mechanism between molecular vibrations and electronic motions (so-called vibronic process). 
Recent efforts to find copper compounds which might serve as models for blue compound formation have been summarized by Dawson. $^{19}$ of a series of $\mathrm{Cu}(\mathrm{II})$ complexes with proteins and certain protein components including imidazole, glycine peptides, lactoglobulin, and bovine serum albumin, the highest molar extinction coefficient reported was 95 at $580 \mathrm{~m} \mu$ for $\mathrm{Cu}($ II)-bistetraglycine. This value is an order of magnitude below the molar extinction coefficient (per $\mathrm{Cu}$ ) of the $\mathrm{Cu}$-proteins listed in Table III. Thus, Dawson concluded that the type of bonding between copper and the ligands in naturally occurring copper proteins, characterized by a high extinction around $600 \mathrm{mw}$ over a relatively wide $\mathrm{pH}$ range, is very different than that responsible for the lower absorption, the $\mathrm{pH}$-dependent wave lengths of $\mathrm{Cu}$ (II) complexes with non-specific proteins or peptides.

Copper complexes with bulky ligands have tetrahedral or some similar structure: like tetrahedral $\mathrm{CuBr}_{4}^{-2}$ or $\mathrm{CuCl}_{4}^{-2}$. These structures have no center of symmetry; thus, the d-d transition is not strictly forbidden by the selection rule. Nevertheless, the intensity $(\varepsilon \cong 50-750)$ is still lower than $\varepsilon=800$. which is observed in a very long wavelength region, e.g. $\mathcal{E}=600$ for $\mathrm{CuCl}_{4}^{-2}$ at $1050 \mathrm{~m} \mu$. However, very strong charge transfer (CT) transitions appear in the visible for these complexes.

Tetrahedral $\mathrm{CuCl}_{4}^{-2}$ and $\mathrm{CuBr}_{4}^{-2}$ have $\mathrm{CT}$ bands shown in $\mathrm{Table}$ IV. 20 No stable $\mathrm{CuI}_{4}^{-2}$ exists because an electron is transferred very easily from the iodine to the $\mathrm{Cu}(\mathrm{II})$ by a small thermal 
excitation. If a stable $\mathrm{CuI}_{4}^{-2}$ existed, one would expect the CT bands to appear in a much redder region than that of $\mathrm{CuBr}_{4}^{-2}$. The position of the CT bands of the imaginary $\mathrm{CuI}_{4}^{-2}$ can be deduced from the data on the CT bands of $\left[\mathrm{Co}\left(\mathrm{NH}_{3}\right){ }_{5} \mathrm{X}\right]^{+2}$ shown in Table V. ${ }^{20} \mathrm{Co}\left(\mathrm{NH}_{3}\right)_{5} \mathrm{I}^{+2}$ has a CT band at a considerably higher wavelength than the corresponding bromide or chloride. Thus we might therefore expect the longest corresponding band for $\mathrm{CuI}_{4}^{-2}$ to be in the $600-700 \mathrm{~m} \mu$ range. The CT bands of tetrahedral $\mathrm{Cu}$ (II) complexes have intensities comparable to those of the absorption bands for the blue color of Cu-proteins (Table III). Whereas the CT bands of the usual planar or octahedral Cu(II) complexes always appear in the UV region.

The stability of the $C u(I I)$ state in Cu-proteins might be less than that of $\mathrm{CuBr}_{4}^{-2}$ or slightly more than that of $\mathrm{CuI}_{4}^{-2}$. Actually the bands responsible for the blue colors of cu-proteins are less energetic than that of $\mathrm{CuBr}_{4}^{-2}$. Therefore, we could expect the Cu-sites responsible for the blue color of $\mathrm{Cu}$ proteins to have tetrahedral structures. This intense color is due to $\mathrm{CT}$ bands, $\pi \longrightarrow 3 \mathrm{~d}$ and/or $\sigma \longrightarrow 3 \mathrm{~d}$ transitions, which appear at a longer wavelength region than that of $\mathrm{CuBr}_{4}^{-2}$. The electron affinity of the site estimated by optical spectra (Franck-Condon principle) is more than that of $\mathrm{CuBr}_{4}^{-2}$ and possibly comparable or slightly less than that of $\mathrm{CuI}_{4}^{-2}$.

A convenient model system for further exploration of the copper locus in copper proteins is now being provided by the copper 
chelate shown in Fig. 5. This is the most intensely blue copper complex known $\mathcal{E}=14,000$ at $610 \mathrm{mli}$ and was first noted, but not characterized, by Nilsson. $^{21}$ It is one of the cuprizones, a series of colored copper chelates of oxalyldihydrazide and various aldehydes or ketones such as acetaldehyde or cyclohexanone. The stoichiometry of this chelate is oxalyldihydrazide to acetaldehyde to $\mathrm{Cu}$ ion of $2: 4: 1$. It also has two additional absorption maxima at 380 and $260 \mathrm{mu}$, similar to several copper proteins, e.g., hemocyanin, $350 \mathrm{~m} \mu$ laccase and ceruloplasmin 404 and $340 \mathrm{~m} \mu .^{22}$

A tetrahedral structure (Fig. 5) is proposed for this chelate because of the high intensity of the blue color. Planar or octahedral structures of $\mathrm{Cu}(\mathrm{II})$ chelates also have blue colors but not as intense. The deep blue color of the chelate in Fig. 5 is believed to be due to charge transfer transitions from the $\pi$ orbitals of the ligand to the central d orbitals or the sigma orbitals of the ligand to the d orbitals. These electronic transitions produce deep absorption in the visible wavelength range for only the tetrahedral or similar structures. We hope to report in detail on some of the other interesting properties of this series of compounds at a later date. 


\section{Oxidation State of Copper Ion in Copper Proteins}

In attempting to describe the sequence of events leading to the reactions of oxygen with the cu-proteins, it is of prime importance to know the oxidation state of the cu-protein in its resting or native state. Oxidized hemocyanin, met-hemocyanin, like (oxidized) met-hemoglobin and (oxidized) met-hemoerythin, is reported to be unable to bind molecular oxygen. ${ }^{10}$ In addition to spectral data, Table III presents a summary of the latest available data on the $\mathrm{Cu}(\mathrm{I})$ or $\mathrm{Cu}(\mathrm{II})$ state of copper proteins as determined by electron spin resonance (ESR) signal or magnetic susceptibility measurements and by chemical measurements, principally the method of Felsenfeld. ${ }^{23}$ Each method suffers from certain limitations. The ESR test is based on the typical paramagnetic nature of $\mathrm{Cu}(\mathrm{II})$ and the diamagnetic nature of $\mathrm{Cu}(\mathrm{I})$. But false negatives for $\mathrm{Cu}(\mathrm{II})$ can be obtained when the $\mathrm{Cu}(\mathrm{II})$ is involved in spin coupling with oxygen or another ligand or in the formation of a diamagnetic dimer or a covalent $\mathrm{Cu}-\mathrm{Cu}$ bond. The chemical method involves the determination of $\mathrm{Cu}(\mathrm{I})$ with a $C u(I)$ preferring reagent, biquinoline, after removal of the copper from the protein with acid. EDTA is also included to chelate $\mathrm{Cu}(\mathrm{II})$ and thus prevent $\mathrm{Cu}(\mathrm{II})$ reduction by various protein functional groups, particularly sH groups. The possibility of reducing the released $C u(I I)$ has been clearly pointed out earlier ${ }^{24}$ (Fig. 6). This reaction is quantitative for reducing agents such 
as glutathione and cysteine (Fig. 6). ${ }^{24}$ Though the reduction of $\mathrm{Cu}(\mathrm{II})$ proceeds most rapidly with cysteine residues, it has been found that $\mathrm{N}$-substituted tyrosines can also reduce $\mathrm{Cu}$ (II) in the presence of a "Cu(I)" preferring agent, 2,9-dimethyl-1, 10-phenanthroline (Neocuproine) at respectable rates. 25

With these basic facts in mind we now proceed to examine the problem from a more theoretical viewpoint. Coordination is a binding between acid and base by partial donation of the electron pair of base to the vacant orbital of acid. This type of charge transfer takes place in the coordination of metal complexes:

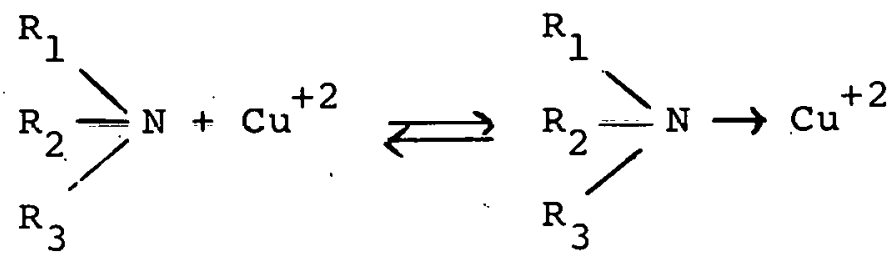

For copper ion complexes such as $\mathrm{Cu}\left(\mathrm{NH}_{3}\right)_{4}^{+2}$, the lone pair electrons of ammonia (ligand) are transferred to the central $\mathrm{Cu}$ (II) ion. Therefore, the net charge of the $\mathrm{cu}$ ion becomes less than +2 (probably less than +1 ). The charge donation due to coordination bond formation gives an electroneutralized $\mathrm{Cu}$ ion. This does not signify the actual reduction of the metal ion. The oxidation state of the central $\mathrm{Cu}$ ion is still divalent or $\mathrm{Cu}(\mathrm{II})$.

In the case of blue copper proteins which have cupric ion as a functional group, very similar electron donation takes place from the coordinating groups of proteins and probably hydration 
water. Sometimes, electron donation of this type may occur from an instantaneously coordinating substrate molecule. Even in this case the oxidation state of $\mathrm{Cu}$ may be still maintained from this electron donation. However, all known substrate molecules have high energy labile $\pi$ electrons. If a tetrahedral local structure can be assumed for the $\mathrm{Cu}$ site of blue colored copper proteins, the $\pi$ electron of the highest occupied orbital of the substrate will merge with the central d orbital of copper, and, accordingly, the positive hole of the d orbital (due to unpaired electron of the $\mathrm{d}^{9}$ shell of $\mathrm{Cu}(\mathrm{II})$ ), will transfer to the ligands including the instantaneously coordinated substrate molecule. Molecular orbital theory predicts the mixing between the d orbitals of copper and $\sigma$ and $\|$ orbitals of ligands is much higher than those of strong field complexes of planar or octahedral structures. This delocalization still does not signify a reduction of cu-ion. However, when the coordination bond is broken, the substrate leaves one of the delocalized "I electrons at the $\mathrm{Cu}$ site resulting in the reduction of $\mathrm{Cu}$ (II) to $\mathrm{Cu}(I)$.

The cation radical formed from the substrate will transfer its proton to some nearby available proton acceptor and then, disproportionation or any other secondary chemical reaction will take place. The proposed cation radical formation has been experimentally observed by Broman et $\underline{a l}^{11}$ by ESR studies 
of the catalytic action of laccase and ceruloplasmin. The reduced coppers can retain their accepted electrons because of the higher stability of the tetrahedral $\mathrm{Cu}(\mathrm{I})$ configuration, and will furnish their electrons to oxygenated site(s) along the hydrated protein helical structure or by direct coupling between the two copper ions.

\section{Hemnryanin}

The deoxygenated hemocyanin contains strictly cuprous ions which do not give an ESR signal or absorption band in the visible. Ila The molecular orbital theory of tetrahedral coordination complex shows that top filled orbitals are an admixture of $d$ orbital of copper and $\pi$ and $\sigma$ orbitals of the ligands and that they are mainly localized at the central metal orbitals. The $t$ orbitals are an admixture of $d \pi, \pi$ and $\sigma$ orbitals, while the e orbitals consist of $d J$ and $\pi$ orbitals. When oxygenated, one of the top filled orbital electrons of each cuprous ion goes into the half.filled $\pi$ orbital of $\mathrm{O}_{2}$ (Fig. 7 ).

This results in a vacancy of the top filled $t$ orbital.. Consequently, charge transfer transitions take place from the $\pi$ and $d$ molecular orbitals, which are mainly composed of the $\pi$ and $\sigma$ orbitals of coordinating ligands, to this vacancy in the top $t$ orbitals. The blue color of hemocyanin arises from the CT induced by the bridged $\mathrm{O}_{2}$, and not the result of CT between the metal and $\mathrm{O}_{2}$ which has been assumed to cause the blue color. The actual 
electronic structure of oxygenated hemocyanin may closely resemble $\mathrm{Cu}(\mathrm{II})-\left(\mathrm{O}_{2}\right)^{-2}-\mathrm{Cu}(\mathrm{II})$. However, the environment (probably due to hydrophobic groups) may be analogous to the case of hemoglobin, which requires that the oxygen molecule return its borrowed electron when deoxygenated. Since the charge separation is not preferred in the hydrophobic environment, this tendency prevents a permanent oxidation of $\mathrm{Cu}(I)$ to $\mathrm{Cu}(\mathrm{II})$. The diamagnetism of oxygenated hemocyanin can be explained by a coupling of unpaired electron of each metal ion, even though the oxidation state of the copper of oxygenated hemocyanin is very close to Cu(II). The hemocyanin structure proposed here can also explain the results of numerous chemical methods to determine the valence or oxidation state of copper in oxy-hemocyanin which involves the separation of the metal ion from the protein prior to the determination and always shows some mixture of $\mathrm{Cu}(\mathrm{I})$ and $\mathrm{Cu}(\mathrm{II})$.

It has been proposed, partly by analogy with hemoglobin, that the combination of oxygen with hemocyanin is accompanied by changes in the conformation of the protein. The distance between the two coppers in hemocyanin can be estimated from the closest packing radius of the water molecule, ca. $1.4 \AA$ A obtained by $\mathrm{x}$-ray studies of ice, by assuming that the deoxygenated hemocyanin has two coordinated water molecules. 


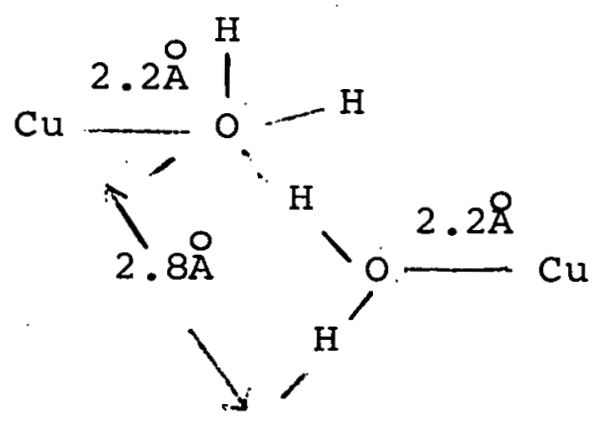

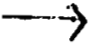

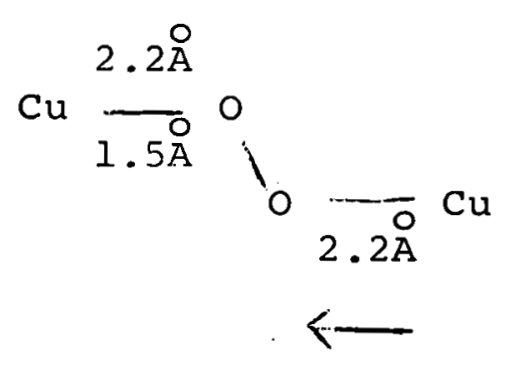

While the 0-0 distances of peroxide, superoxide and oxygen show systematic contraction from $1.5 \AA$ (for $\mathrm{O}_{2}{ }^{2-}$ ) to $1.2 \AA$ (for $\mathrm{O}_{2}$ ), in each case they are less than $1.5 \AA$.

Assuming the same bond length for $\mathrm{Cu}-0,2.2 \AA$, for the oxygenated and the deoxygenated, we find a remarkable shift of two coppers due to the oxygenation. Therefore we would expect some conformational change in the protein part due to the oxygenation, very similarly to the conformational change observed for hemoglobin. However, the evidence for these changes in hemocyanin recently summarized by Manwell, ${ }^{26}$ is admittedly equivocal, particularly because of the difficulty in distinguishing changes in the associated solvent from actual changes in the protein. closely involved is the question of whether hemocyanin has functional subunits, since subunits have been reported which bind oxygen less avidly than the aggregate molecules. The disaggregation of hemocyanin effected by lowering divalent ion concentration, particularly calcium ion, has also been suggested as a mechanism for modifying the oxygen transport function of hemocyanin. 27 


\section{Copper Oxidase}

The top filled orbitals of $\mathrm{Cu}($ II) site have one vacancy which behaves as an electron acceptor for the substrate. The intense blue color or CT bands of Cu-proteins are due to the electron transition from the bonding $\pi$ and $\sigma$ orbitals to this vacancy in the $t$ orbitals.

The Cu(I) site which is found originally in the enzyme or converted from $\mathrm{Cu}(I I)$ by reduction has a closed shell for the top filled orbitals. When oxygenated, one of the top filled orbital electrons will transfer to the oxygen molecule and create a vacancy in the $t$ orbitals. However, it depends upon the environment of the site of the oxygenation whether the electron transfer is tentative and will be restored upon deoxygenation, or whether the electron transfer results in the reduction of oxygen. Probably $\mathrm{Cu}$ proteins which behave as oxidases have active sites surrounded by hydrophilic groups and water, which facilitate the oxidation of $\mathrm{Cu}(\mathrm{I})$ by $\mathrm{O}_{2}$. Because of unstable $t$ electrons, there is a possibility of a two electron transfer from the $t$ orbitals of each closely located copper to the oxygen, resulting in the direct reduction of $\mathrm{O}_{2}$ to $\mathrm{H}_{2} \mathrm{O}$. However, it is not reasonable to assume this direct reduction, unless those two copper sites are joined to neighboring reduced cu sites (reduced by substrate) through some electron conducting mechanism such as a hydrated helical protein structure. 
Water or Hydrogen Peroxide as the Product of $\mathrm{Cu}$ Ion or Cu-Enzyme Catalyzed Oxidations

One of the reaction characteristics which has been used to distinguish between copper ion catalyzed oxidations and certain closely related enzymic oxidations has been the production of a stoichiometric amount of hydrogen peroxide by the free metal ion catalysis." 28 None of the more familiar copper oxidases such as tyrosinase, ascorbate oxidase, laccase or ceruloplasmin produce hydrogen peroxide. ${ }^{19,28,52}$ Yet it has been long known or accepted that the copper ion catalyzed oxidation of ascorbate, p-phenylenediamine (PPD) and uric acid produce hydrogen peroxide. $28,29,52$ In recent years several new copper oxidases have been discovered which, in contrast to the previously mentioned enzymes, do produce stoichiometric amounts of hydrogen peroxide. These include galactose oxidase, ${ }^{30}$ monoamine oxidase, ${ }^{17}$ diamine oxidase, 32 and uricase. $^{29}$ The enzyme, uricase, of course had been known for a long time but the evidence for its being a copper enzyme has been reported only recently. ${ }^{29}$ The reactions known to involve hydrogen peroxide production are as follows:

Ascorbate $+\mathrm{O}_{2} \stackrel{\mathrm{Cu}^{+2}}{\longrightarrow} \mathrm{H}_{2} \mathrm{O}_{2}+$ Dehydroascorbate p-phenylenediamine $+\mathrm{O}_{2} \stackrel{\mathrm{Cu}^{+2}}{\longrightarrow} \mathrm{H}_{2} \mathrm{O}_{2}+$ oxidation products of $\mathrm{pPD}$ Uricate $+\mathrm{O}_{2} \underset{\mathrm{pHII}}{\stackrel{\mathrm{Cu}^{+2}}{\longrightarrow}} \mathrm{H}_{2} \mathrm{O}_{2}+$ Oxidation products of uricate Uric Acid $+\mathrm{O}_{2} \stackrel{\text { Uricase }}{\longrightarrow} \mathrm{H}_{2} \mathrm{O}_{2}+$ Allantoin $+\mathrm{CO}_{2}$ 
D-Galactose $+\mathrm{O}_{2} \stackrel{\text { Galactose Oxidase }}{\longrightarrow} \mathrm{H}_{2} \mathrm{O}_{2}+$ D-Galacto-hexodialdose

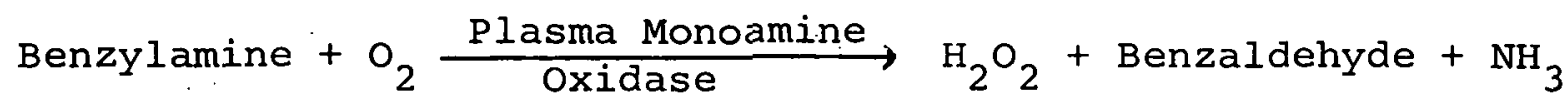

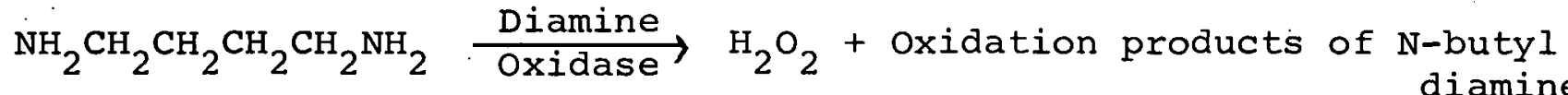

We now raise the question as to why some of cu-oxidases produce hydrogen peroxide while others produce water. We can evaluate the thermodynamic possibilities from the data presented in Table VI. The E'o values at neutral $\mathrm{pH}$ 's virtually exclude hydrogen peroxide as a product of certain blue cu-enzymes, e.g. laccase, ceruloplasm, catalyzed oxidations since they have potentials which are lower than the $\mathrm{H}_{2} \mathrm{O}_{2} / \mathrm{O}_{2}$ couple of $-0.26 \mathrm{~V}$. The $\mathrm{H}_{2} \mathrm{O} / \mathrm{O}_{2}$ potential establishes water as a possible product of the reaction between the $\mathrm{Cu}(\mathrm{I})$ form of the enzyme and oxygen. Either reaction is possible for free copper ion catalysis with a potential of $-0.15 \mathrm{~V}$. It is of interest that perhydroxy, $\mathrm{HO}_{2}$, is excluded as a product of any cuprous or ferrous ion oxidation if its potential is as high as has been reported ${ }^{63}-0.13 \mathrm{~V}(\mathrm{pH}=0)$ or $+0.55 \mathrm{~V}$ when corrected to $\mathrm{pH} 7.0$.

It is apparent that the cu-enzymes which produce hydrogen peroxide must have potentials around $-0.26 \mathrm{~V}$ or less if the $\mathrm{Cu}(\mathrm{I}) / \mathrm{Cu}(\mathrm{II})$ reaction is involved. These enzymes would then have a significantly different structure from the cu-enzymes listed in Table VI, since the latter have E'o's less than $-0.33 \mathrm{~V}$. The low potentials for laccase, ceruloplasmin and other $\mathrm{Cu}$-proteins 
are probably due to the stabilization of the tetrahedrally coordinated $C u(I)$ form of the enzyme. Clearly this kind of stabilization cannot exist for the $C u(I)$ form of hydrogen peroxide producing Cu-enzymes. We would expect the coordination of copper ion in these enzymes to be either planar or octahedral. It is of interest to note that the effect of ligands is to uniformly decrease the $\mathrm{Cu}(\mathrm{I}) / \mathrm{Cu}(\mathrm{II})$ potential but to consistently increase the $\mathrm{Fe}(\mathrm{II}) / \mathrm{Fe}$ (III) couple. The simplest explanation is to assume that these effects are due to preferential stabilization of $\mathrm{Cu}(\mathrm{I})$ and Fe(III) by. the respective ligands.

Correlation of the Number of Enzyme Copper Atoms and Water or Hydrogen Peroxide Formation

The discussions on the relative potentials merely delineate the possible reactions. Which reaction actually occurs is determined by independent kinetic factors. A major problem posed by the exclusion of perhydroxy and hydrogen peroxide as the product of certain Cu-enzyme catalyzed oxidations is that there must eventually be a four electron transfer. As shown in Table VII, those enzymes which produce water have four or more copper atoms per molecule. Favorable positioning of at least two of these copper atoms would facilitate a four electron reduction of oxygen to water. Except for monoamine oxidase the $\mathrm{Cu}$-enzymes which produce hydrogen peroxide and thus serve as two electron transfer oxidases have only one copper atom per molecule of enzyme. Monoamine oxidase is reported $17,33,34$ to have four copper atoms per enzyme 
molecule but still produces hydrogen peroxide, the only copper enzyme with more than one copper atom per molecule known to produce hydrogen peroxide. It is also unusual in that it has two molecules of pyridoxal phosphate per $255,000 \mathrm{~g}$. , the molecular weight of monoamine oxidase. Thus there is a structural basis for the unique behavior of this enzyme. The presence of pyridoxal phosphate suggests that we might expect a different reaction mechanism for monoamine oxidase, involving an oxidative removal of an amino group through transfer to pyridoxal phosphate. It is also conceivable that the detailed mechanism of monoamine oxidase deamination could involve direct participation of only one or two of the total of four coppers found in the molecule. This effects only a one or two electron or hydride ion transfer. Another possible exception to this correlation is Neurospora tyrosinase, which has only one cuprous ion per $33,000 \mathrm{~g}^{35}$, for which no hydrogen peroxide has been reported as a product, although its absence has not been verified. No data is available on the oxidation-reduction potential of the $\mathrm{Cu}(\mathrm{I}) / \mathrm{Cu}(\mathrm{II})$ of this enzyme which might reflect on the likelihood of hydrogen peroxide as a possible product.

The foregoing considerations may also apply to copper enzymes which have two copper atoms per molecule but no example of this has yet been found. Of interest and value in properly interpreting mechanisms of these enzymes will be isotopic studies 
such as those of Bentley and Neuberger, ${ }^{36}$ who proved that the oxygen in the hydrogen peroxide produced by uricase came directly from molecular oxygen. Additional oxygen isotope studies would be helpful in elucidating these mechanisms further.

In general these. two electron transfer oxidases do not serve as important terminal oxidases. Their major role appears to be to effect certain specific syntheses and metabolic changes, e.g., galacto-hexodialdose formation; uric acid and aromatic monoamine disappearance. As Mason ${ }^{37}$ has emphasized, the disadvantages of reduction mechanisms which result in the formation of such reactive intermediates as superoxide or hydrogen peroxide are twofold: (1) a random attack upon functioniny components of the cell, and (2) the inefficiency of such oxidations compared to oxidation to water because half or more of the electron affinity of the oxygen molecule is thereby lost to metabolism. Thus the enzymes which produce hydrogen peroxide have probably been relegated to a minor role in metabolism.

All mechanisms proposed for the two or four electron transfer oxidases assume a cyclic valence change involving reduction of $\mathrm{Cu}(\mathrm{II})$, probably to $\mathrm{Cu}(\mathrm{I})$-protein by substrate, usually forming free radical intermediates and then the subsequent oxidation of $\mathrm{Cu}(I)$-protein by molecular oxygen. This has been confirmed for several copper enzymes, e.g., ascorbate oxidase, 38 ceruloplasmin, ${ }^{11}$ laccase, ${ }^{11}$ dopamine hydroxylase, ${ }^{31}$ and also copper ion catalysis. 1,3. It remains to be confirmed for the 
enzymes which produce $\mathrm{H}_{2} \mathrm{O}_{2}$. It was mentioned earlier that the ESR signal of plasma amine oxidase does not change from the $\mathrm{Cu}(\mathrm{II})$ state during enzymic activity. 34

While the ESR method is virtually the only one now available for the study of cyclic changes in copper, the possibility of false negatives makes conclusions based on it only tentative. For example, if during the cyclical exchange, the various reaction rates are such that the steady state level of $\mathrm{Cu}$ (II) during enzymic activity remains at more than $95 \%$ of the total copper, the presence of the remaining $5 \%$ of $\mathrm{Cu}(\mathrm{I})$ might not be detectable. An oxidative deamination taking place in the presence of pyridoxal phosphate or some other prosthetic group is also possible, but it would be difficult to deduce a consistent mechanism for oxidizing the primary alcohol of galactose and the production of hydrogen peroxide without an intermediate change in $\mathrm{Cu}(\mathrm{II})$ state of the enzyme, particularly when no other prosthetic group or coenzyme is involved.

For the enzyme uricase a mechanism that does not involve any valence change for the copper ion has been proposed by Mahler and his associates. 29 Uricase is a difficult enzyme to prepare and characterize and, in the light of more current methods, the evidence for its copper content must be regarded as mostly indirect. As shown in Fig. 8, $\mathrm{Cu}$ (II) ion is pictured as providing (1) a locus of simultaneous attachment for both 
the electron donor, uric acid, and the electron acceptor, oxygen, (2) a strong polarizing force for drawing electrons away from uric acid, and (3) a means of shuttling electrons to oxygen from orbitals shared with uric acid. The ultimate products of uricase action, probably arise from nonenzymatic side reactions which occur subsequently. The reaction with oxygen is depicted as a displacement by oxygen of one of the protein$\mathrm{Cu}$ bonds. Another possibility is a transition from the strong planar copper complex of coordination number of 4 to the much weaker octahedral copper complex of coordination number of 6 . The $\mathrm{Cu}$ (II) Catalyzed Oxidation of Ascorbic Acid

Probably the most widely studied of the free copper ion catalyses is the $\mathrm{Cu}(\mathrm{II})$ catalyzed oxidation of ascorbate. ${ }^{39-42}$ Although this reaction has found wide use, particularly in the study of $\mathrm{Cu}(\mathrm{II})$ complexing reactions, ${ }^{39}$ the exact mechanism has still not been unequivocally elucidated, despite many intense efforts. ${ }^{39-42}$ The basic features of the reaction which must be accounted for include:

1. The catalytic role of $\mathrm{Cu}(\mathrm{II})$ and the changing order of the reaction with respect to $C u(I I)$ as shown in Fig. 9.

2. The oxidation of ascorbate to one mole of dehydroascorbate consuming one mole of $\mathrm{O}_{2}$ and producing one mole of $\mathrm{H}_{2} \mathrm{O}_{2}$.

3. The cyclic interconversion of $\mathrm{Cu}(\mathrm{I})$ and $\mathrm{Cu}(\mathrm{II})$. 
4. In the neutral $\mathrm{pH}$ range (5-9) the reactive species is the ascorbate monoanion which is converted to the relatively stable ascorbate semiquinone, recently isolated and characterized by Levandoski et al. $^{42 a}$ The sequence of reactions may be pictured as follows:

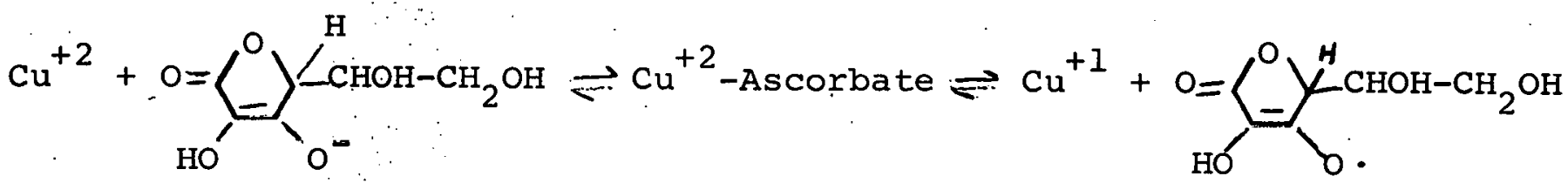

This free radical could react with $\mathrm{O}_{2}$ to produce dehydroascorbate, but it is also possible for it to react with another $\mathrm{Cu}$ (II), regenerated, if necessary, by reaction with oxygen as shown in the following reactions :

$$
\mathrm{Cu}^{+2}+\mathrm{O}=\underbrace{\mathrm{O}}_{\mathrm{OO}} \underbrace{\mathrm{H}-\mathrm{CHOH}-\mathrm{CH}_{2} \mathrm{OH}}_{\mathrm{O}} \rightleftharpoons \mathrm{Cu}^{+1}+\mathrm{H}^{+}+\mathrm{O}=\underbrace{\mathrm{O}}_{\mathrm{O}} \mathrm{C}_{\mathrm{O}}^{\mathrm{H}}-\mathrm{CHOH}-\mathrm{CH}_{2} \mathrm{OH}
$$

In order to account for stoichiometric amount of hydrogen peroxide by the most simple kinetic mechanism possible, it would be convenient to first postulate the formation of the perhydroxy radical $\mathrm{HO}_{2} \cdot$ as the result of a one electron transfer from $\mathrm{Cu}^{+1}$ to $\mathrm{O}_{2}$. But a consideration of the potentials involved (see Table VI) makes the formation of perhydroxy extremely unlikely, although it has not been excluded experimentally. If $\mathrm{HO}_{2}$ ' were formed, it would not survive for any extended period because of its high reactivity with $\mathrm{Cu}(\mathrm{I})$ or other intermediates and its strong tendency to dismutate in aqueous solutions to hydrogen peroxide and oxygen. For $\mathrm{Cu}(\mathrm{I})$ oxidation, the reduction of oxygen to $\mathrm{H}_{2} \mathrm{O}_{2}$ or water are both 
thermodynamically feasible but the formation of water could involve a four electron transfer which is virtually impossible when the $\mathrm{Cu}$ ions are not assembled in a favorable structure such as in a Cu protein: We propose a two electron transfer by either of the following two mechanisms:

$\mathrm{Cu}^{+1}+\mathrm{O}_{2} \rightleftharpoons \mathrm{Cu}^{+1}-\mathrm{O}_{2} \rightleftharpoons \mathrm{Cu}^{+1} \underset{\mathrm{Cu}_{2}{ }^{+1}-\mathrm{O}_{2} \rightleftharpoons \mathrm{Cu}_{2}^{+2}-\left(\mathrm{O}_{2}\right)^{-2} \rightleftharpoons 2 \mathrm{H}^{+}}{\rightleftharpoons} 2 \mathrm{Cu}^{+2}+\mathrm{H}_{2} \mathrm{O}_{2}$

or

$\mathrm{Cu}^{+1}+\mathrm{O}_{2} \rightleftharpoons \mathrm{Cu}^{+1}-\mathrm{O}_{2} \rightleftharpoons \mathrm{Cu}^{+2}-\left(\mathrm{O}_{2}\right)^{-1} \stackrel{\mathrm{Cu}^{+1}}{\rightleftharpoons} \mathrm{Cu}^{+1}-\left(\mathrm{O}_{2}\right)^{-1}-\mathrm{Cu}^{+2} \rightleftharpoons$ $\mathrm{Cu}^{+2}-\left(\mathrm{O}_{2}\right)^{-2}-\mathrm{Cu}^{+2} \stackrel{2 \mathrm{H}^{+}}{\rightleftharpoons} \mathrm{H}_{2} \mathrm{O}_{2}+2 \mathrm{Cu}^{+2}$

These reactions, while not being the only ones possible, could account for the overall stoichiometry and other features cited.

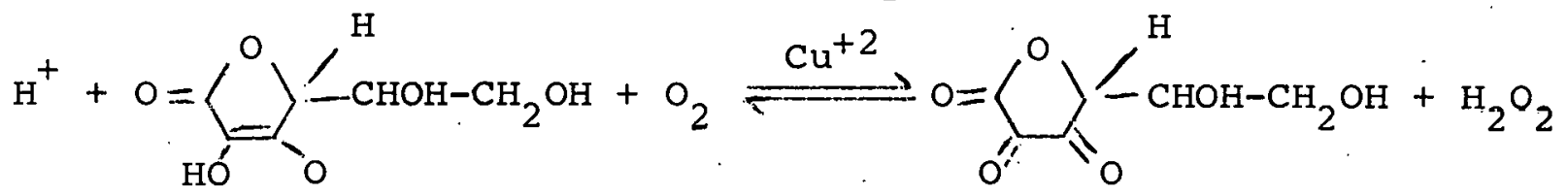

This brief discussion of these mechanisms has not included possible chain mechanisms or reactions which are bimolecular with respect to $\mathrm{Cu}(\mathrm{II})$. It is also of interest to note that the $\mathrm{Cu}$ (II) catalyzed oxidations of p-phenylenediamine and uric acid also results in the production of stoichiometric amounts of $\mathrm{H}_{2} \mathrm{O}_{2}$. Mechanisms of Cu-Enzyme Catalyzed Oxidations

Except for tyrosinase (and possible galactose oxidase) which qualifies as a mixed function oxidase (monoxygenase), most of the $\mathrm{Cu}$ oxidases are thought to be electron transfer oxidases. Their uniqueness, probably shared with many Fe enzymes, may arise 
from the fact that their action is characterized by a one electron transfer which is ultimately multiplied to a 2 or 4 electron transfer to oxygen.

With the above correlations and information on the state of oxidation and with the helpful discussions and suggestions of Mason ${ }^{37}$ and Mahler, ${ }^{43}$ we have attempted to formulate general oxidative mechanisms for the cu-enzymes which should take into account the basic features of these reactions summarized below:

1.: One or two electron transfer oxidases which could result in formation of hydrogen peroxide as a primary product.

2. Four electron transfer oxidases which produce water and usually occur in two steps of two electrons at a time.

3. The number of copper atoms per molecule of enzyme or active enzyme subunit.

4. The probable oxidation state of copper in the enzyme molecule during rest and activity.

5. The necessity of treating oxygen in its diatomic state until it undergoes at least partial oxidation to $\left(\mathrm{O}_{2}\right)^{-2}$ prior to any cleavage of the oxygen molecule.

6. The sequence of reactions of the catalytic copper with oxygen and oxidizable substrates, e.g., when the enzyme exists as $\mathrm{Cu}^{+2}$ in the resting or prereaction state, the first reaction is a one electron reduction of each $\mathrm{Cu}^{+2}$ to $\mathrm{Cu}^{+1}$. The probable single exception is tyrosinase 
where all the copper atoms appear to exist as $\mathrm{Cu}^{+1}{ }^{59}$ There also may be enzymes in which no cyclic change in the valence of $\mathrm{Cu}$ ion occurs which will have to be described by different mechanisms.

7. Finally, these mechanisms are consistent with numerous accessory facts including the production of free radical intermediates, exchangeability of the copper ions, induction periods, copper ion in representative model systems, etc.

It has been realized that any mode of action involving the cyclical valence change of $\mathrm{Cu}^{+2} \rightleftharpoons \mathrm{Cu}^{+1}$ raised important problems arising from the fact that the metal undergoes a one-electron change, the oxidizable substrate a one or two electron change and the oxygen molecule eventually, either a two or four electron change. It seems likely that most substrates can reduce $\mathrm{Cu}^{+2}$ to $\mathrm{Cu}^{+1}$ by a one electron transfer. The most pressing dilemma has been one of electron inventory and relates to the reduction of the oxygen molecule to either peroxide or water. The following oxygen reduction reactions are possible:

\section{Consecutive one electron reduction:}

$$
\mathrm{Cu}^{+\mathrm{I}}+\mathrm{O}_{2} \rightleftharpoons \mathrm{Cu}^{+\mathrm{I}}-\mathrm{O}_{2} \rightleftharpoons \mathrm{Cu}^{+2}-\left(\mathrm{O}_{2}\right)^{-1}+\mathrm{Cu}^{+1} \stackrel{2 \mathrm{H}^{+}}{\rightleftharpoons} 2 \mathrm{Cu}^{+2}+\mathrm{H}_{2} \mathrm{O}_{2}
$$

Two electron reduction:

$$
\mathrm{Cu}_{2}^{+1}+\mathrm{O}_{2} \rightleftharpoons \mathrm{Cu}_{2}^{+1}-\mathrm{O}_{2} \rightleftharpoons \mathrm{Cu}_{2}^{+2}-\left(\mathrm{O}_{2}\right)^{-2} \stackrel{2 \mathrm{H}^{+}}{\rightleftharpoons} \mathrm{Cu}^{+2}+\mathrm{H}_{2} \mathrm{O}_{2}
$$


Four electron reduction:

$\mathrm{Cu}_{4}^{+1}+\mathrm{O}_{2} \rightleftharpoons \mathrm{Cu}_{4}^{+1}-\mathrm{O}_{2} \rightleftharpoons \mathrm{Cu}_{4}^{+2}-\left(\mathrm{O}_{2}\right)^{-4} \stackrel{4 \mathrm{H}^{+}}{\rightleftharpoons} \mathrm{Cu}_{4}^{+2}+2 \mathrm{H}_{2} \mathrm{O}$

As explained earlier, we must exclude perhydroxy $\left(\mathrm{HO}_{2}\right)$ formation which forbids a single one electron reduction. The expected product for these and analogous reactions is hydrogen peroxide or further oxidation states of oxygen. The relatively high stability of hydrogen peroxide may explain how two electron transfer reactions can lead exclusively to hydrogen peroxide, but unless the cu-enzyme itself possesses catalase activity, a four electron transfer is necessary for water formation from oxygen. None of the Cu-enzymes have significant catalase activity. In this connection, it is of interest that while there are several Cu-oxidases with one copper per molecule, none have been found to have two $\mathrm{Cu}$ atoms per molecule.

If the enzyme has a sufficient number of adjacent and accessible metal ions as $\mathrm{Cu}(\mathrm{I})$, the requisite number of electrons can be transferred. A final alternative is suggested by the formation of highly active free radical substrate intermediates such as the ascorbate-free radical, which could reduce a Cu(II) immediately so that the resulting $\mathrm{Cu}(\mathrm{I})$ can transfer another electron to an attached partially reduced oxygen. A number of these possibilities are depicted in Tables VIII and IX for two and four electron transfer oxidases with a different number of electron acceptances. 
In Table VIII, the first two reactions provide for a one electron donation followed by two consecutive one electron acceptances by oxygen. A simultaneous two electron acceptance by $\mathrm{O}_{2}$ would simplify the problem of hydrogen peroxide formation by a series of analogous reactions but no two electron copper oxidases are known. The possibility that the enzyme molecule acts in pairs still remains: Certain Cu-oxidases with more than two $\mathrm{Cu}$ atoms per molecule might react with oxygen two $\mathrm{Cu}$ units at a time. Numerous reasonable paths for an ultimate four electron transfer are available. For example, the $\operatorname{Encu}_{2}{ }^{+2}\left(\mathrm{O}_{2}\right)^{-2}$ complex could react with an intermediate substrate species to convert a two electron transfer to an overall four electron transfer as shown:

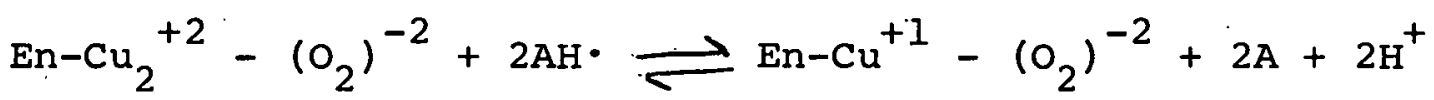

$$
\begin{aligned}
& \mathrm{En}-\mathrm{Cu}_{2}^{+1}-\left(\mathrm{O}_{2}\right)^{-2} \rightleftharpoons \mathrm{En}-\mathrm{Cu}_{2}^{+2}-\left(\mathrm{O}_{2}\right)^{-4} \stackrel{4 \mathrm{H}^{+}}{\rightleftharpoons} 2 \mathrm{H}_{2} \mathrm{O}+\mathrm{En}-\mathrm{Cu}_{2}^{+2}
\end{aligned}
$$

For those copper enzymes which have at least 4 accessible $\mathrm{Cu}(I)$ (e.g...ceruloplasmin, ascorbate oxidase, tyrosinase), we can postulate a simultaneous or four electron transfer on an intramolecular basis as depicted in Table IX. For the other copper proteins, we must assume intermolecular reactions or some mechanism other than a four electron transfer, but it is not likely to involve the $0-0$ bond or the production of peroxide intermediates of other oxygen species for which there is no good evidence to date. The implication of a concerted reaction with 
one oxygen molecule, as Broman has emphasized for ceruloplasmin, suggests that optimally four reactable copper ions must be adjacent to one another, although two copper atoms may be sufficient if two electron transfer takes place for each copper as discussed previously. Another possible consequence is that the activation of the oxygen molecule may be at least partially due to energy accruing from a distorted tertiary structure arising from conformational changes during enzyme oxidation. Certain subtle structural changes have been associated with the function of ceruloplasmin. The role of the four additional $\mathrm{Cu}(I)$ atoms of ceruloplasmin may serve in a special way as shown in Table IX. The association of the $\mathrm{Cu}_{2}^{+1} \ldots \mathrm{Cu}_{2}{ }^{+2}$ is shown only to indicate some mechanism for electron transfer but not necessarily a direct charge transfer, nor any $\mathrm{Cu}^{+1}-\mathrm{Cu}^{+2}$ interaction in the resting enzyme.

\section{Mechanism of Tyrosinase Catalysis}

We now come to tyrosinase, heretofore regarded as a unique Cu-enzyme because it is a mixed function oxidase and includes among its functions the hydroxylation of monophenols to diphenols and the oxidation of diphenols to quinones, although these activities may be due to different subunits. $37,44,44 a$ Chemically, tyrosinase is the only cu-oxidase in which all the copper ion appears to remain in the reduced form even in the resting state. ${ }^{47,59}$ Many other Cu-enzymes, where the resting 
state of the copper is $\mathrm{Cu}(\mathrm{II})$, involve reaction with oxygen after reaction with the substrate since it is presumed that only the $\mathrm{Cu}(\mathrm{I})$ states interact with oxygen and the substrate converts the $\mathrm{Cu}(\mathrm{II})$ to $\mathrm{Cu}(\mathrm{I})$. This order is reversed in tyrosinase and $\mathrm{EnCu}^{+1}-\mathrm{O}_{2}$ forms must occur before the substrate is oxidized. As with ascorbate oxidase, exchange with free $\mathrm{Cu}^{64}$ ion is observed only during catalytic activity of tyrosinase. ${ }^{44 \mathrm{~b}, 44 \mathrm{c}}$ Fig. 10 depicts a widely proposed mechanism of tyrosinase action, a possible early form of the enzyme-oxygen complex is EnCu $_{2}{ }^{+2}(\mathrm{OOH})^{-1}$, which has been proposed as the hydroxylating form of tyrosinase. This hypothesis receives support by analogy from detailed studies of certain ortho-hydroxylating model systems by Konecny ${ }^{45}$ and Havinga and his associates. ${ }^{46}$ Konecny ${ }^{45}$ found that the system $\mathrm{H}_{2} \mathrm{O}_{2}-\mathrm{Cu}(\mathrm{II})$ will hydroxylate benzene and benzoate to phenol and salicylate. Havinga et $\underline{\text { al }}^{45}$ extended this to systems more closely related to tyrosinase in the $\mathrm{Cu}(\mathrm{II})$ catalyzed orthohydroxylation of phenols and aniline in the presence of amines. The hydroxylating intermediate is proposed as $-\mathrm{Cu}^{+2}(\mathrm{OOH})^{-1}$. Hydrogen peroxide can be formed by subsequent oxidation of some of the oxidation products. In the intermediate drawn in Fig. 10, $\mathrm{Cu}(\mathrm{II})$ acts as an acid catalyst which polarizes the $0-0$ bond so that it will cleave ionically with the electron pair remaining on the oxygen near the copper. The resulting $\left(\mathrm{OH}^{+}\right)$fragment hydroxylates the benzene ring in a typical electrophilic displacement reaction. As emphasized by Ingraham, ${ }^{46 a}$, in this 
reaction, $\mathrm{Cu}(\mathrm{II})$ acts in the same way as two protons in other acid catalyzed hydrogen peroxide oxidations.

In its other major type of reaction involving direct oxidation of diphenols to quinones and beyond, tyrosinase is not atypical of other cu-enzymes. The ability of the protein to keep all its copper in the $\mathrm{Cu}(I)$ state even in the presence of oxygen until 'substrate interacts, is a striking feature but is also not unique. From ESR data Malmström and Neilands ${ }^{47}$ believe that four of the eight (8) coppers of ceruloplasmin are maintained permanently in the $\mathrm{Cu}(\mathrm{I})$ state. There are also several $\mathrm{Cu}(\mathrm{I})$ reagents, such as biquinoline, and neocuproine which form extremely stable chelates with $\mathrm{Cu}(I)$, thus insulating $\mathrm{Cu}(\mathrm{I})$ against the oxidizing effects of dissolved oxygen.

\section{Ceruloplasmin as an Ascorbate Oxidase}

Copper ion catalysis has been compared most extensively with enzymic catalysis using ascorbate as substrate. Pertinent data on the catalysis of ascorbate oxidation by $\mathrm{Cu}($ II), squash ascorbate oxidase, and ceruloplasmin are shown in Table $\mathrm{x}$.

The fact that the $\mathrm{Cu}$ ion catalysis of ascorbate oxidation is unique in producing hydrogen peroxide has been noted earlier. The pH optima of these reactions are clearly different. The $\mathrm{K}_{\mathrm{m}}$ with respect to $\mathrm{O}_{2}$ for ceruloplasmin is surprisingly low, $4 \times 10^{-6} \mathrm{M}$, whereas the protein of ascorbate oxidase does not contribute significantly to oxygen binding. Both enzymes have 
much smaller $\mathrm{K}_{\mathrm{m}}$ 's with respect to ascorbate. Obviously plant ascorbate oxidase is a much more specific and effective catalyst in terms of catalyzing the oxidation of a limited group of substrates and in greatly increasing the catalytic activity per atom of $\mathrm{Cu}$.

While some doubts had been raised about the ability of ceruloplasmin to catalyze ascorbate oxidation, ${ }^{48}$ we believe that this has now been firmly established. 28 Crucial data comparing the properties of $\mathrm{Cu}(\mathrm{II})$ and ceruloplasmin catalysis are summarized in Table XI. Except for the fact that these catalytic systems have oxygen, ascorbate and copper in common, they are different in virtually every other respect. Numerous kinetic differences, such as dependence on $\mathrm{pH}$, the effect of ascorbate concentration and relative activation energy, have been found. As discussed earlier, $\mathrm{Cu}$ (II) reactions produce stoichiometric amounts of $\mathrm{H}_{2} \mathrm{O}_{2}$ where the enzyme produces none. Perhaps the most important difference is the specific sensitivity of ceruloplasmin to inhibition by citrate and the specific inhibition of $\mathrm{Cu}$ (II) reactions by neocuproine, serum albumin and certain other copper ion chelates.

We emphasize that establishing the catalytic activity of ceruloplasmin independent of copper ion catalysis is a matter of some subtlety as illustrated in Fig. 11. It can be seen that at over $10^{-4} \mathrm{M}$ ascorbate concentrations, the activity of this copper protein is less than that for a corresponding amount of 
$\mathrm{Cu}(\mathrm{II})$. However, the serum ascorbate concentrations, which are generally in the $10^{-5} \mathrm{M}$ range, fall well within the range where ceruloplasmin activity is quantitatively greater, particularly in the presence of serum proteins such as albumin. From these relationships we concluded that there must be some control of the ascorbate oxidase activity of this serum enzyme. This regulation appears to be effected through the inhibition of this copper oxidase by prevailing serum levels of citrate, data for which is shown in Table XII. 49 Also as shown in Table XII, neither neocuproine or serum albumin. affected the ascorbate oxidase of ceruloplasmin in contrast to the situation with respect to $\mathrm{Cu}(\mathrm{II})$ ion. Though the molecular activity of ceruloplasmin is relatively low, it must be remembered that its concentration in normal sera is relatively high, $2 \times 10^{-6} \mathrm{M}$, comprising 1 out of every 300 of serum protein molecules.

The enzymic activity of ceruloplasmin could be sheer coincidence or accidental. Oxidation of ascorbate to dehydroascorbate which is not coupled to phosphorylation or terminal oxidation might be regarded as biochemically wasteful. Under certain conditions, however, it may be desirable to have a convenient serum mechanism for this reaction. Martin and Mecca 50 have shown that dehydroascorbic acid penetrates the brain, eye, and erythrocytes more rapidly and to a greater extent than ascorbic acid. Except for this we must conclude at the moment 
that the biological function of ceruloplasmin is still related to copper transport or transfer.

\section{Catalytic Action of Ceruloplasmin}

As the final part of this brief survey of copper proteins and oxygen, we consider the catalytic activity of ceruloplasmin further because recent studies with a variety of current methods have made this particular oxidase one of the most detailed studied:Cu-enzymes. 11 While typical kinetic studies of ceruloplasmin are quite feasible, the slowness of its reactions have permitted simultaneous electron spin resonance and spectrophotometric measurements in a stopped-flow apparatus to provide more specific kinetic data than with any other $\mathrm{Cu}$ oxidase.

Many aspects of the catalytic activity of ceruloplasmin

and its inhibition have been recently reviewed. 50 In addition to ascorbate, two other classes of compounds serve as substrates for ceruloplasmin: One group have in common the fact that they are all reducing agents including hydrosulfite, hydroxylamine, thioglycolate and hexacyanoferrate. The third group--aromatic polyamines and polyphenols--are by far the most numerous and well-studied substrates including $\mathrm{p}$-phenylenediamine (PPD) and serve as the basis for the close comparison of ceruloplasmin to laccase.

A most complete study of a large number of arylamine and polyphenol substrates of ceruloplasmin has been made by Levine 
and Peisach. 51 They showed that the rate of oxidation of a large number of these kinds of substrates are directly related to Hammettsigma values. Compounds having substituents with high positive sigma values (electron withdrawing) show little or no activity, whereas compounds with negative sigma values (electron releasing) were reactive. Thus they concluded that the ease of oxidation of the substrate increased with increasing electron density in the ring. The compounds tested can be placed in the following order with respect to ease of oxidation:

pPd $>\mathrm{N}, \mathrm{N}$-dimethyl $\mathrm{pPD}>\mathrm{N}$-methyl $\mathrm{pPD}>\mathrm{p}$-aminophenol > hydroquinone $>\mathrm{N}, \mathrm{N}-$ dimethyl $\mathrm{m}-\mathrm{PD}>\mathrm{m}-\mathrm{PD}$

For the oxidation of pPD, Peisach and Tievine ${ }^{55}$ proposed the following reaction sequence which proceeds through four steps:

(1) The formation of a charge transfer complex between substrate and ceruloplasmin-Cu(II).

$$
\mathrm{AH}_{2}+\text { ceruloplasmin-Cu(II) } \rightleftharpoons \mathrm{AH}_{2} \text {-ceruloplasmin-Cu(II). }
$$

(2) Transfer of a single electron from substrate to ceruloplasmin-Cu(II) to form a free radical. $\mathrm{AH}_{2}$-ceruloplasmin-Cu(II) $\rightleftharpoons \mathrm{AH} \cdot+\mathrm{H}^{+}+\operatorname{ceruloplasmin}-\mathrm{Cu}(\mathrm{I})$.

(3) The loss of another electron from the free radical either through disproportionation or by reaction with the enzyme.

$2 \mathrm{AH} \cdot \underset{\mathrm{A}:}{\longrightarrow}+\mathrm{AH}_{2}$ $\mathrm{AH} \cdot+$ ceruloplasmin $\mathrm{Cu}(\mathrm{II}) \rightleftharpoons \mathrm{A}:+\mathrm{H}^{+}+$ceruloplasmin-Cu(I). 
(4) The diradical species then reacts with more $\mathrm{pPD}$ to form a product usualiy measured in colorometric ceruloplasmin tests and the ceruloplasmin-Cu(I) is oxidized by molecular oxygen.

$$
\mathrm{A}:+\mathrm{AH}_{2} \rightleftharpoons \text { Product }
$$

A similar mechanism was proposed for durenediamine oxidation in which the diradical product rearranges and is hydrolyzed. Broman et ${ }^{l i}$ suggested that the radical intermediate formed in the oxidation of $\mathrm{PPD}$ is the $\mathrm{AH}_{2}{ }^{+}$and not the $\mathrm{AH} \cdot$, however, the principle involved is the same.

Peisach and Levine 55 confirmed the earlier work of Holmberg and Laurell. 56 that monoamines (aniline) and monophenols (pentamethylphenol) are not oxidized by ceruloplasmin. The factors common to all aryl substrates tested are that each possesses a minimum of two electron supplying groups, and no strong electron withdrawing groups, suggesting definite electronic requirements in addition to the steric requirements.

Walaas et al $\underline{\text { al }}^{57}$ have studied the oxidation of catecholamines by ceruloplasmin. The mechanism of the reaction is as follows:

$$
\begin{aligned}
& \text { ceruloplasmin-Cu(II) }+ \text { catecholamine } \stackrel{\mathrm{k}_{1}}{\longrightarrow} \text { ceruloplasmin-Cu(I) } \\
& \quad+\text { catecholamine (oxid.) } \\
& \text { ceruloplasmin-Cu(I) } \mathrm{n}+\frac{\mathrm{n}}{4} \mathrm{O}_{2}+\mathrm{nH}^{+} \longrightarrow \text { ceruloplasmin-Cu(II) } \\
& \quad+\frac{\mathrm{n}}{2} \mathrm{H}_{2} \mathrm{O}
\end{aligned}
$$

The catecholamine oxidation product may be a free radical which reacts further as in the mechanism outlined previously. 
The relative rates of oxidation of typical catecholamine substrates expressed as $x_{1}$ in $\mathrm{m}^{-1}$ sec $^{-1}$ are: dopamine, 143; noradrenaline, 120; adrenaline, 99; isopropylnoradrenaline, 85; dopa, 7. The larger rate constant for compounds with unsubstituted amine side chains suggest that this group is involved in the interaction with ceruloplasmin. If the $\pi$ electrons are primarily involved in the binding of the pPD series referred to earlier, the interaction of the catecholamines may occur at a different site on ceruloplasmin.

The oxidation of $\mathrm{NADH}$ and $\mathrm{NADPH}$ has been observed in a system containing ceruloplasmin and appropriate substrates. walaas and Walaas 58 have shown that the reaction proceeds as:

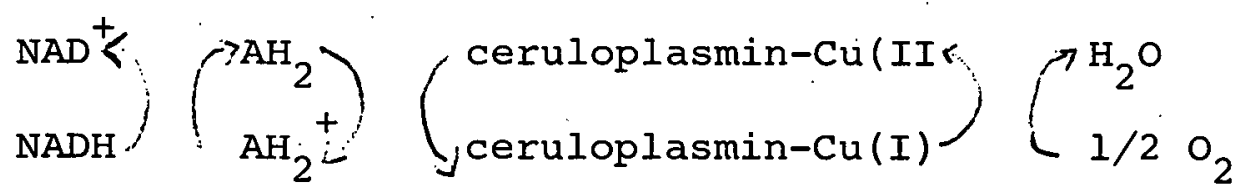

Thus a free radical is probably an intermediate of the ceruloplasmin catalyzed reaction. These radicals in turn oxidize the NADH or NADPH by acting as one electron acceptors. There is no evidence of a direct reaction between NADH and ceruloplasmin. By measuring the number of moles of $\mathrm{NAD}^{+}$or $\mathrm{NADP}^{+}$formed in five minutes, they determined the relative rates as follows:

Dimethyl pPD Noradrenaline PPD Adrenaline Serotonin $\begin{array}{llllll}\text { with } \mathrm{NADH} & 0.195 & 0.185 & 0.14 & 0.04 & 0.03\end{array}$ $\begin{array}{llllll}\text { with } \mathrm{NADPH} & 0.20 & 0.20 & 0.17 ; & 0.06 & 0.08\end{array}$ 
An intensive study of the role of copper in the catalytic action of both laccase and ceruloplasmin using combined fast reaction techniques and ESR measurements was recently reported by Broman et al. ${ }^{11}$ The kinetics of the reduction of the $\mathrm{Cu}$ (II) of ceruloplasmin by various substrates were studied using ESR changes. The rate of formation and decay of a positively charged free radical formed from $\mathrm{NPD}$ was estimated as shown in Fig. 12, which summarizes data for two different concentrations of $\mathrm{O}_{2}$. With only $0.15 \mathrm{mM} \mathrm{O}_{2}$, the oxygen was rapidly depleted and the PPD oxidation product reached a maximum and quickly decayed. In pure $\mathrm{O}_{2}$, the $\mathrm{Cu}(\mathrm{II})$ was quickly converted to $\mathrm{Cu}(\mathrm{I})$, but the radical persisted for several minutes until the pPD (or $o_{2}$ ) was exhausted. The mechanism postulated by these workers which accounts for the data is as follows:

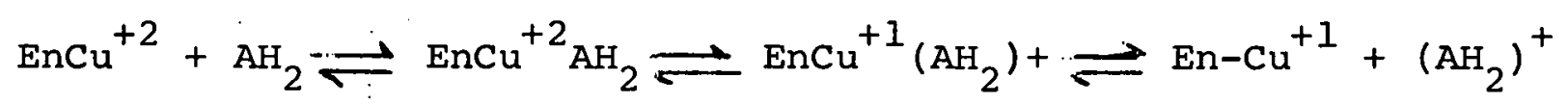
$\mathrm{EnCu}_{4}^{+1}+\mathrm{O}_{2}+4 \mathrm{H}^{+} \rightleftarrows \mathrm{EnCu}_{4}^{+2}+2 \mathrm{H}_{2} \mathrm{O}$

From data similar to Fig. 12, Broman et $\underline{1}^{11}$ were able to estimate many of the parameters involved in ceruloplasmin catalyzed oxidation of various substrates. These data shown in Table XI clearly indicate the superiority of pPD as a substrate, include values for $t_{1 / 2}$, the approximate half-time for reduction to the steady state level, $\mathrm{c}_{\mathbf{s}} / \mathrm{c}_{\mathrm{O}^{\prime}}$ the bivalent fraction of the valencechanging $\mathrm{Cu}$ during the steady state, $\mathrm{k}_{1}$, the first order rate 
constant for the reduction, $\mathrm{q}^{\prime} \mathrm{O}_{2}$ and $\mathrm{q}^{\prime \prime} \mathrm{O}_{2}$, the rate of oxygen consumption calculated by two different methods, $t_{s}$, the duration of the steady state, and finally, $k_{2}$, the first order rate constant for the reoxidation reaction. The data is also consistent with the postulated mechanism which involves the reduction of $\mathrm{En}-\mathrm{Cu}(\mathrm{II})$ by the substrate followed by reoxidation by $\mathrm{O}_{2} \cdot$ 


\section{REFERENCES}

1. Frieden, E.: The Complex Copper of Nature. In Horizons in Biochemistry. Edited by M. Kasha and B. Pullman. New York, Academic Press, 1962, pp. 461-96.

2. Mason, H. S., Fowlks, W. L. and Peterson E.: Journal of the American Chemical Society, 77:2914, 1955.

3. Schubert, J.: . Copper and Peroxides in Radiobiology and Medicine. Springfield, Illinois, C. C. Thomas, 1964.

4. Oxygen in the Animal Organism. Edited by F. Dickens and E. Neil. New York, MacMillan Co:, 1964.

5.. Chance, B.: Ibid.., p. 148.

6. Griffith, J. S.: Ibid., p. 141 .

7. Millikan, G. A.: The Kinetics of Blood Pigments: Haemocyanin and Haemoglobin. Journal of Physiology, 79:158, 1933.

8. Hartridge, H. and Roughton, F.J.W.: A Method of Measuring the Velocity of Very Rapid Chemical Reaction. Proceedings of the Royal Society of London, Al04:376, 1923.

9. Prosser, C. L.: Respiratory Functions of Body Fluids. In Comparative Animal Physiology. Edited by C. L. Prosser. Philadelphia, W. B. Saunders Co., 1950, pp. 198-237.

10. Felsenfeld, G. and Printz, M. P.: Specific Reactions of Hydrogen Peroxide with the Active Site of Hemocyanin. The Formation of "Methemocyanin." Journal of the American Chemical Society, $81: 6259,1959$.

11. Broman, L., Malmström, B. G., Aasa, R. and Vangard, T.: The Role of Copper in the Catalytic Action of Laccase and ceruloplasmin. Biochimica et Biophysica Acta, 포:365, 1963. 
11a. Nakamura, T. and Mason, H. S.: An Electron Spin Resonance study of Copper Valence in Hemocyanin. Biochimica et Biophysica Acta Res. Com. $\underline{3}: 297,1960$.

12. Chance, B.: Cellular oxygen Requirements. Federation Proceedings, 16:671, 1957 .

13. Thimann, K. V., Yocum, C. S. and Hackett, D. P.: Terminal Oxidases and Growth in Plant Tissues III. Terminal oxidation in Potato Tuber Tissue. Archives of Biochemistry and Biophysics, 53:239, 1954 .

14. Frieden, E. and Maggiolo I.: Activation and other Properties of Ascorbic Acid Oxidase. Biochimica et Biophysica Acta, 24:42, 1957. 15. Osaki, S.: unpublished data. 1964.

16. Broman, L.: Chromatographic and Magnetic Studies of Human Ceruloplasmin. Acta Societatis Medicorum Upsaliensis, 69:75, 1964. 17. Yamada; H. and Yasunobu, J.: Monoamine Oxidase I. Purification, Crystallization, and Properties of Plasma Monoamine Oxidase, Journal of Biological Chemistry, 237:1511, 1962.

18. Gray, H. B.: Molecular Orbital Theory for Transition Metal Complexes, Journal of Chemical Education, 41:2, 1964.

19. Dawson, C. R.: The Copper Protein, Ascorbic Acid Oxidase. Annals of the New York Academy of Sciences, 88:353, 1960. 20. Jorgensen, C. K.: Absorption Spectra and Chemical Bonding in Complexes. Pergamon Press, 1961.

21. Nilsson, G.: Über eine, neue Farbreaktion des oxaldihydrazids. żeitschrift für Analytische Chemie, 153:161, 1956.

22. Tsuchida, T.: Symposium on Cu Protein, Biophysics, 1 :42, 1961. 23. Felsenfeld, G.: The Determination of Cuprous Ion in Copper Proteins. Archives of Biochemistry and Biophysics, 87:247, 1960. 
24. Frieden, E.: Colorimetric Measurements of Cuprous Ion Formation to Detect Certain Reducing Agents as Illustrated with Cysteine, Glutathione and Serum Albumin. Biochimica et Biophysics Acta, 27:414, 1958.

25. Spiegel, L. B. and Frieden, E.: unpublished data, 1961.

26. Manwell, C.: Chemistry, Genetics and Function of Invertebrate Respiratory Pigments-Configurational Changes and Allosteric Effects. In oxygen in the Animal Organism. Edited by F. Dickens and E. Neil. New York, MacMillan Co., 1964, pp. 49-119.

27. Larimer, J. L. and Riggs, D. F.: Properties of Hemocyanins I. Effect of Calcium Ion on Oxygen Equilibrium of Crayfish Hemocyanin. Comparative Biochemistry and Physiology, 13:35, 1964.

28. Osaki, S., McDermott, J. and Frieden, E.: Proof for the Ascorbate Oxidase Activity of Ceruloplasmin. Journal of Biological Chemictry, 239:3570, 1964 .

29. Mahler, H. R.: Uricase. In The Enzymes. Edited by P. Boyer, H. A. Lardy and K. Myrbach. New York, Academic Press, 1963, pp. 285-96. 30. Cooper, J.A.D., Smith, W., Bacila, M. and Medina, H.: . Galactose oxidase from Polyporus circinatus, Fr.. Journal of Biological Chemistry, 234:445, 1959.

31. Levine, S. Y. and Kaufman, S.: Studies on the Enzyme Catalyzing the Conversion of 3,4-Dihydroxyphenylethylamine to Norepinephrine. Journal of Biological Chemistry, 236:2043, 1961.

32. Hill, J. M. and Mann, P.J.G.: Further Properties of the Diamine oxidase of Pea Seedlings. Journal of Biological Chemistry, 91:171, 1964.

33. Yamada, H., Gee, P., Ebata, J., and Yasanobu, K.: Monoamine oxidase VI. Physiocochemical Properties of Plasma Monoamine Oxidase. Biochimica et Biophysica Acta, 81:165, 1964. 
34. Yamada, H., Yasunobu, K. J., Yamano, H., and Mason, H.S.: Copper in Plasma Amine Oxidase. Nature 198:1092, 1963.

35. Fling, M., Horowitz, N. H. and Heinemann, S. F.: The Isolation and Properties of Crystalline Tyrosinase from Neurospora. Journal of Biological Chemistry, 238:2045, 1963.

36. Bentley, R. and Neuberger, A.: The Mechanism of the Action of Uricase. Biochemical Journal, 52:694, 1952.

37. Mason, H. S.: Mechanisms of Oxygen Metabolism. In Advances in Enzymology, Vol. 19. Edited by F. F. Nord, New York, Interscience Publishers, Inc., 1957, pp. 79-235.

38. Poillon, W. W. and Dawson, C. R.: On the Nature of Copper in Ascorbate Oxidase II. The Role of Prosthetic copper in the Enzyme's Function. Biochimica et Biophysica Acta, 77:27,37, 1963. 39. Frieden, E. and Alles, J.: Subtle Interactions of Cupric Ion with Nealeic Acid and components. Journal of Biological Chemistry, 230:797, 1958.

40. Weissberger, A. and LuValle, J.: Oxidation Processes XVII. The Autoxidation of Ascorbic Acid in the Presence of Copper. Journal of the American Chemical Society, 66:700, 1944.

41. Nord, H.: Kinetics and Mechanism of the Copper Catalysed Autoxidation of Ascorbic Acid. Acta Chemica Scandinavica, 9:442, 1955.

42. Scaife, J. F:: The Catalysis of Ascorbic Acid Oxidation by Copper and its Complexes with Amino Acids, Peptides and Proteins. Canadian Journal of Biochemistry and Physiology, 37:1049, 1959. 42a. Levandoski, N. G., Baker, E. M. and Canham, J. E.: A Monodehydro Form of Ascorbic in the Autoxidation of Ascorbic Acid to Dehydroascorbic Acid. Biochemistry, 3: 1465, 1964. 
43. Mahler, H. R.: . Interrelationships with Enzymes. In Mineral Metabolism, Vol. I. Part B. Edited by C. L. Comar and F. Bronner. New York, Academic Press, 1961, pp. 743-879.

43a. Orgel, L. E.: Enzyme-Metal-Substrate Complexes as Coordination Compounds. In Biochemical Society symposium, No. 15 . Edited by E. M. Crook, Cambridge, Cambridge University Press, 1956, pp. 8-20.

44. Bouchilloux, S., McMahill, P. and Mason, H. S.: Journal of Biological Chemistry, 238:1699, 1963.

44a. Jolley, R. L., Jr. and Mason, H. S.: Journal of Biological Chemistry, 240: pcl489, 1965 .

44b. Dressler, $H$. and Dawson, C. R., Biochimica et Biophysica Acta, $\underline{45}: 508,515,1960$.

44c. Magee, R. J. and Dawson, C. R.: The Exchangeability of Copper at Active Sites in Ascorbic Acid Oxidase. Archives Biochemistry Biophysics, 99:338, 1962 .

45. Konecny, J. O.: Hydroxylation of Benzene in a Solution of Hydrogen Peroxide and Copper sulfate. Journal of the American Chemical Society, 76:4993, 1954.

46. Brackman, W. and Havinga, E.: The Oxidation of Phenols, with Copper-Amine Catalysts and its Relation to the Mode of Action of Tyrosinase II. The oxidation of Napthols with Tertiary Amines as Catalysts. III. Kinetics of the Oxidation of Monohydric Phenols with Copper-Morpholine Complex as a Homogeneous Catalyst. IV. Relations between Hydrogen Peroxide and the Catalytic oxidation of Phenols. V. Reaction Mechanisms. Rec. Trav. Chim., 94:1021, 1070, 1107, 1955 .

47. Malmström, B: G. and Neilands, J. B.: Metallo Proteins. Annual Review of Biochemistry, 33,331, 1964. 
48. Morrell, A. G., Aisen, P. and Scheinberg, I. H.: Is Ceruloplasmin an Ascorbic Acid Oxidase? Journal of Biological. Chemistry, 237:3455, 1962 .

49. Osaki, S., McDermott, J. and Frieden, E.: Citric Acidas the Principal Serum Inhibitor of Ceruloplasmin, Journal of Biological Chemistry, 239:pc364, 1964.

50. Martin, G. R. and Mecca, C. E.: Studies on the Distribution of L-Ascorbic Acid in the Rat. Archives of Biochemistry and Biophysics, 93:110, 1961 .

51. Peisach, J. and Levine, W. G.: Mechanism of CeruloplasminCatalyzed oxidations. Biochimica et Biophysica Acta, 77:615, 1963.

5.2. Holmberg, C. G. and Laurell, C. B.: Investigations in Serum Copper. III. Ceruloplasmin as an Enzyme. Acta Chemica Scandanavica, $\underline{5}: 476,1951$.

53. Walaas, O., Walaas, E., Henvikson, A. and Loustad, R.: The Influence of Catecholamines on the Visible Absorption and on the Electron Spin Resonance Absorption spectrum of Ceruloplasmin. Acta Chemica Scandanavica, 17:S5263, 1963.

54. Walaas, O. and Walaas, E.: Oxidation of Reduced Phosphopyridine Nucleotides by p-Phenylenediamines, Catecholamines and Serotonin in the Presence of Ceruloplasmin. Archives of Biochemistry and Biophysics, 95:151, 1961.

55. Winzler, R. J.: The Respiration of Baker's Yeast at Low. oxygen Tension. Journal of Cellular and Comparative Physiology, $17: 263,1941$.

56. Wahlbörg, A. and Frieden, E.: Comparative Interaction of Thyroxine änd Analogs with CuII. Paper submitted for publication. 57. Malmström, B. G.: Two Forms of copper in copper containing Oxidases. Oxidases and Related Redox Systems. Edited by T. E. King, H. S. Mason and M. Morrison, New York, John Wiley and Sons, Inc. (In Press). 
58. Stark, G. K. and Dawson, C. R.: Ascorbic Acid Oxidase, in The Enzymes; Academic Press, 1963.

59. Kertesz, D. and Zito, R., Phenolase in oxygenases. Academic Press, 1962 .

60. Frieden, E., Unpublished data.

61. Longmuir, I.: Respiration Rate of Rat Liver Cells at Low oxygen Concentrations. Biochemical Journal, 65:378, 1957.

62. Baender, A. and Kiese, M.: Die Wirkung des Sauerstoffübertragenden. Ferments in Mitochondrien aus Rattenlebern bei niedrigen Sauerstoffdrucken. Archives of Experimental Pathology and Pharmacology, 224:312, 1955 .

63. Latimer, W.: The oxidation States of the Element and Their Potential in Aqueous Solutions, 2nd Edition. Prentice-Hall, Inc., New York, 1952, p. 340 .

64. Lardy, H. A.: Respiratory Enzymes, Burgess Publishing Co., 1949 .

65. Blumberg, W. E., Eisinger, J., Arsen, P., Morell, A. G. and Schemberg, I. H.: Physical and Chemical Studies on Ceruloplasmin I. The Relation Between Blue Color and the Valence states of Copper. Journal of Biological Chemistry, 238:1675, 1963.

66. Nakamura, T.: Purification and Physico-Chemical Properties of Laccase. Biochimica et Biophysica Acta; 30:44, 1958.

67. Horio, T., Sekequ, I., Higaslu, J.: and Okunuki, K.: In Haemetin Enzymes (Edited by Falk, J. E., Lemberg, R. and Marton, R. K.), Pergamon Press, London, 1961, pp. 302-311.

68. Katoh, S:, Shiratori, I. and Takamiya, A.: Journal of Biochemistry, Tokyo, 51:32, 1962 .

69. Omura, T:: Journal of Biochemistry, Tokyo, 45:264, 305, 309, 344,1961 . 
SOME PROPERTIES OF THE COPPER ENZYMES AND PROTEINS

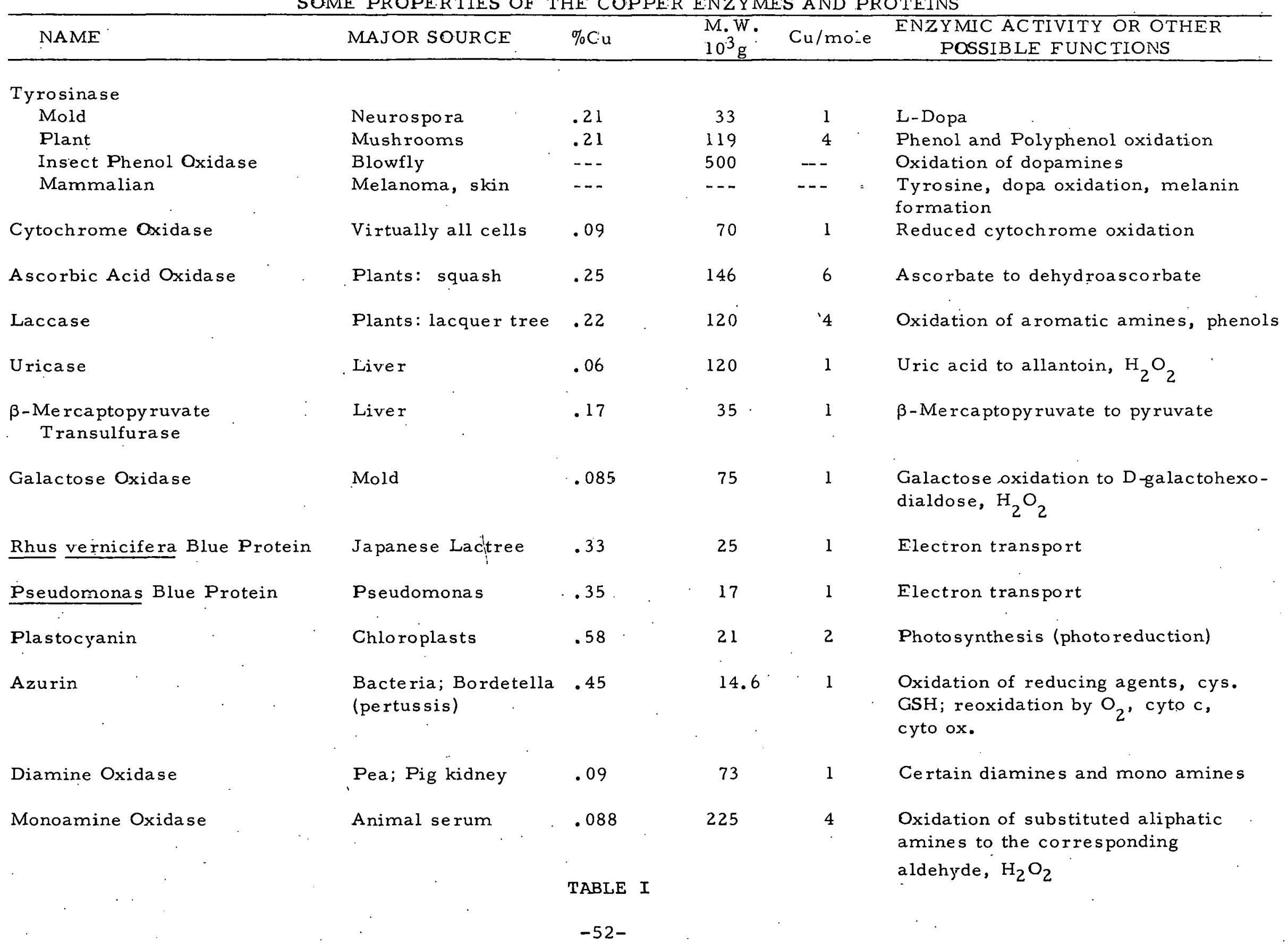


TABLE I (Cont.)

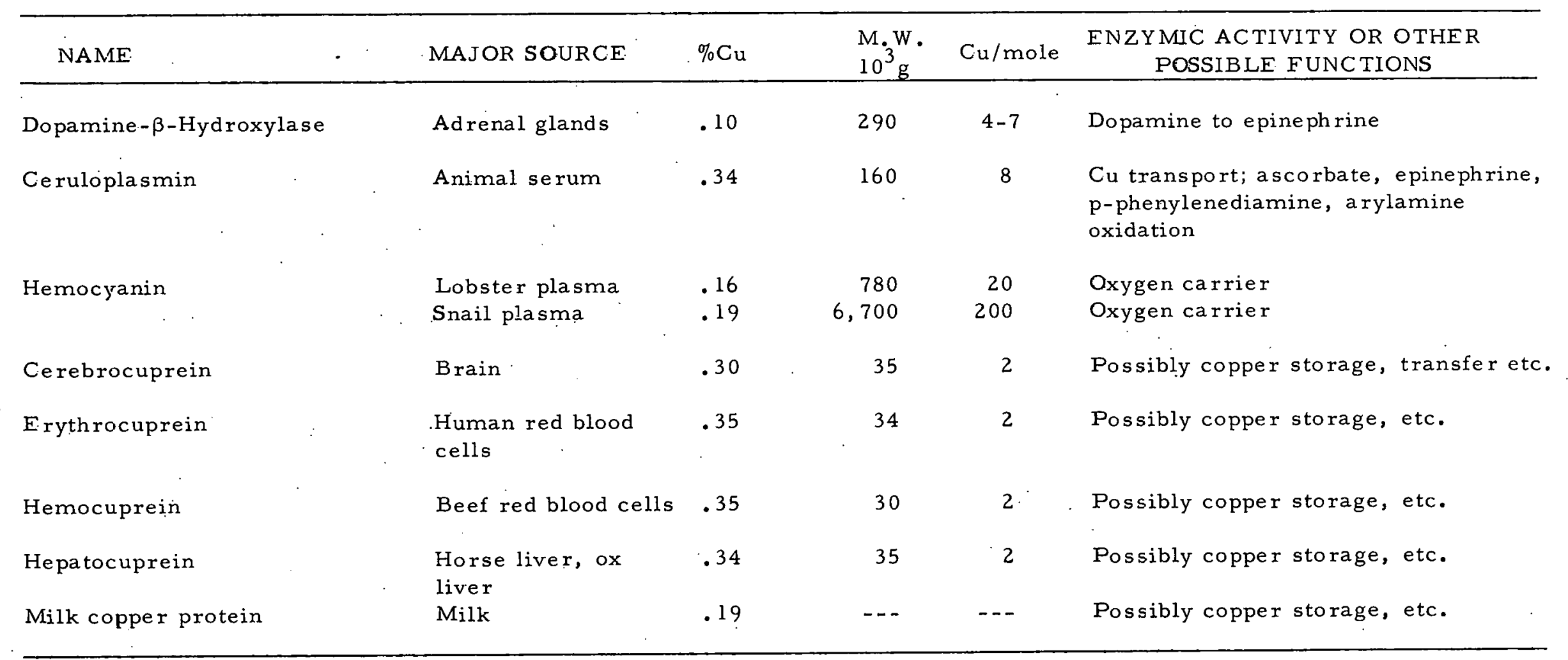

There have been additional reports of less well-characterized copper proteins from various sources, including Brewer's yeast $(0.12 \% \mathrm{Cu})$, vaccinia virus $(0.05 \% \mathrm{Cu})$. 
TABLE II

HALF SATURATION OXYGEN CONCENTRATIONS OF COPPER PROTEINS

ESTIMATED HALF SATURATION

MOLAR CONCENTRATION

$\mathrm{CU}$ PROTEIN

$\left[\mathrm{O}_{2}\right]$ at $200( \pm 2)$

REFERENCE

HEMOCYANINN

$4 \times 10^{-6} \mathrm{M} *$ to

Millikan ${ }^{7}$

$6.5 \times 10^{-5}$

Prosser ${ }^{y}$

CYTOCHROME OXIDASE

$4 \times 10^{-6}$

Chance ${ }^{12}$

ASCORBATE OXIDASE

$2.2 \times 10^{-4}$

Thimann et $\underline{a l}^{13}$

CERULOPLASMIN

$3.9 \times 10^{-6}$

Osaki 15

$\mathrm{Cu}(I I)$ CATALYSIS

OF ASCORBATE

$2 \times 10^{-4}$

Frieden 60

URICASE

$2 \times 10^{-4}$

Mahler et al ${ }^{43}$

TYROSINASE

$5.5 \times 10^{-5}$

Osaki $^{15}$

BAKER'S YEAST

$1.7 \times 10^{-6}$

RAT LIVER CELLS

NUMEROUS MICROORGANISMS

RAT LIVER MITOCHONDRIA
$5 \times 10^{-7}$

$1 \times 10^{-8}$

$3 \times 10^{-6 \text { to }}$

$8 \times 10^{-9}$
Winzler 55

Longmuir 61

Longmuir 61

Baender and Kiesse 62

* These correspond to 2 and $36 \mathrm{~mm}$ Hg respectively. 
TABLE III

OXIDATION STATE OF CU AND THE BLUE COLOR OF CU PROTEINS

\begin{tabular}{|c|c|c|c|c|c|}
\hline $\mathrm{Cu}$ PROTEIN & $\mathrm{Cu} / \mathrm{MOLE}$ & $\begin{array}{c}\text { ESR } \\
\text { METHOD } \\
\end{array}$ & $\begin{array}{l}\text { CHEMICAL } \\
\text { METHOD }\end{array}$ & $\begin{array}{r}\text { VISIBLE } \\
\text { ABSORPTION } \\
\end{array}$ & $\begin{array}{l}\text { LIGHT } \\
\text { PROPERTIES } \\
\end{array}$ \\
\hline - & . & & & $\underset{\mathrm{m}}{\operatorname{Maximum}}$ & $\begin{array}{c}\text { Molar } \\
\text { Extinction } \\
\text { Coefficient }\end{array}$ \\
\hline HEMOCYANIN & $20-200$ & $\mathrm{Cu}^{+1}$ & $\mathrm{Cu}^{+1}$ & \multicolumn{2}{|c|}{ NO COLOR } \\
\hline OXYHEMOCYANIN & $"$ & $\mathrm{Cu}^{+1}$ & $\mathrm{Cu}^{+1}=\mathrm{Cu}^{+2}$ & $580-5$ & 750 \\
\hline AZURIN & 1 & $\mathrm{Cu}^{+2}$ & & 625 & 3500 \\
\hline $\begin{array}{l}\text { GALACTOSE } \\
\text { OXIDASE }\end{array}$ & 1 & $\mathrm{Cu}^{+2}$ & & \multicolumn{2}{|c|}{ ( PINK-YELLOW) } \\
\hline $\begin{array}{l}\text { MONOAMINE } \\
\text { OXIDASE }\end{array}$ & 4 & $\mathrm{Cu}^{+2}$ & & 480 (PINK) & 1100 \\
\hline $\begin{array}{l}\text { DIAMINE } \\
\text { OXIDASE }\end{array}$ & 1 & & $\mathrm{Cu}^{+2}$ & 500 (PINK) & \\
\hline $\begin{array}{l}\text { TYROSINASE, } \\
\text { MUSHROOM }\end{array}$ & 4 & $4 \mathrm{Cu}^{+1}$ & $4 \mathrm{Cu}^{+1}$ & No $\mathrm{CC}$ & COLOR \\
\hline NEUROSPORA & 1 & $\mathrm{Cu}^{+1}$ & $\mathrm{Cu}^{+1}$ & & \\
\hline $\begin{array}{l}\text { LACCASE, } \\
\text { LACQUER TREE }\end{array}$ & 6 & $\mathrm{Cu}^{+2}$ & & 610 & 1300 \\
\hline FUNGAL & 4 & $\begin{array}{l}2 \mathrm{Cu}^{+1} \\
2 \mathrm{Cu}\end{array}$ & . & & \\
\hline $\begin{array}{l}\text { DOPAMINE } \\
\text { HYDROXYLASE }\end{array}$ & $4-7$ & $\mathrm{Cu}^{+2}$ & & No $\mathrm{Cc}$ & COLOR \\
\hline $\begin{array}{l}\text { ASCORBATE } \\
\text { OXIDASE }\end{array}$ & 8 & & $1 \mathrm{Cu}^{+1}, 3 \mathrm{Cu}^{+2}$ & 606 & 770 \\
\hline CERULOPLASMIN & 8 & $\begin{array}{l}4 \mathrm{Cu}^{+1}+2 \\
4 \mathrm{Cu}^{+1}\end{array}$ & $\mathrm{Cu}^{+1}, \mathrm{Cu}^{+2}$ & 605 & 1200 \\
\hline
\end{tabular}


CHARGE TRANSFER BANDS OF TETRAHEDRAL COPPER COMPLEXES 20

$\underline{\underline{m}} \underline{\boldsymbol{E}} \quad \underline{\text { Assignment }}$

$\begin{array}{llll}\mathrm{CuCl}_{4}{ }^{2-} & 377 & 1700 & \pi-3 \mathrm{~d} \\ & 274 & 4000 & \sigma-3 \mathrm{~d} \\ \mathrm{CuBr}_{4}{ }^{2-} & & & \\ & 585 & 1000 & \pi-3 \mathrm{~d} \\ & 512 & 2100 & \pi-3 \mathrm{~d} \\ & 338 & 4200 & \sigma-3 \mathrm{~d} \\ & 266 & 2300 & \sigma-3 \mathrm{~d}\end{array}$


TABLE V

CHARGF TRANSFER BANDS OF $\left[\mathrm{CO}\left(\mathrm{NH}_{3}\right) 5^{\mathrm{X}}\right]^{2+20}$

\begin{tabular}{lcccc} 
Complex & $\begin{array}{c}\text { CT }(\pi-d) \\
\mathrm{m} \mu\end{array}$ & $\boldsymbol{E}$ & $\begin{array}{c}\text { CT } \\
\text { m } \mu\end{array}$ & $\boldsymbol{\varepsilon}$ \\
\hline $\mathrm{Co}\left(\mathrm{NH}_{3}\right)_{5} \mathrm{Cl}$ & 270 & 600 & 278 & 20,000 \\
$\mathrm{Co}\left(\mathrm{NH}_{3}\right)_{5} \mathrm{Br}$ & 313 & 850 & 253 & 18,500 \\
$\mathrm{Co}\left(\mathrm{NH}_{3}\right)_{5} \mathrm{I}$ & 380 & 2,700 & 287 & 16,500
\end{tabular}


STANDARD OXIDATION-REDUCTION POTENTIALS ${ }^{1}$

$\underline{E_{0}(p H=0)} \cdot \underline{E_{0}^{\prime}(p H 7.0)}$

$\mathrm{K} / \mathrm{K}^{+}$

$\mathrm{HO}_{2} / \mathrm{O}_{2}$

Hemoglobin $\mathrm{Fe}^{+2} / \mathrm{Fe}^{+3}$

Ascorbate/Dehydroasc.

$\mathrm{Cu}^{+1} / \mathrm{Cu}^{+2}$

$\mathrm{H}_{2} \mathrm{O}_{2} / \mathrm{O}_{2}$

Cytochrome c; Red./Ox.

Hydroquinone/quinone

$\mathrm{Fe}(\mathrm{CN}) 6^{-4} / \mathrm{Fe}(\mathrm{CN}) 6^{-3}$

Pseudomonas aeruginosa

$$
\text { blue Cu protein }{ }^{2}
$$

Plastocyanin ${ }^{3}$

R. vernicifera

blue cu protein 4

Ceruloplasmin ${ }^{5}: \mathrm{Cu}^{+1} / \mathrm{Cu}^{+2}$

Laccase ${ }^{6} ; \mathrm{Cu}^{+1} / \mathrm{Cu}^{+2}$

(THREE) $\mathrm{Cu}$-Proteins; $\mathrm{Cu}^{+1} / \mathrm{Cu}^{+2}$

$\mathrm{CuCl} / \mathrm{Cu}^{+2}$

$\mathrm{CuBr} / \mathrm{Cu}^{+2}$

$\mathrm{H}_{2} \mathrm{O}_{2} \mathrm{O}_{2}$
$\mathrm{CuI} / \mathrm{Cu}$

$\mathrm{Cu}(\mathrm{CN})_{2}^{-} / \mathrm{Cu}^{+2}$

$\mathrm{H}_{2} \mathrm{O} / \mathrm{H}_{2} \mathrm{O}_{2}$
$+2.93$

$+0.13$

$-0.39$

$-0.15$

$-0.68$

$-0.46$

$-0.70$

$-0.36$
$+0.55$

$+0.14$

$-0.06$

$-0.26$

$-0.26$

$-0.28$

$-0.33$

$-0.37$

$-0.42$

$-0.39$

$-0.42$

-0.33 to -0.42

$-0.54$

$-0.64$

$-1 \cdot 23$

$-0.82$

$-0.86$

$-1.12$

$-1.77$

${ }^{1}$ Data at $20-30^{\circ}$ from Latimer ${ }^{63}$ or Lardy ${ }^{64}$.

${ }^{2}$ Horio et a! ${ }^{67}$.

${ }^{3}$ Katoh et al ${ }^{68}$.

${ }^{4}$ omura ${ }^{69}$.

${ }^{5}$ Blumberg et al ${ }^{65}$.

$6_{\text {Nakamura }} 66$ 
TABLE VII

CORRELATION OF NUMBER OF ENZYME COPPER ATOMS AND $\mathrm{H}_{2} \mathrm{O}_{2}$ FORMATION

Cu Enzyme or Water or

Catalytic system $\mathrm{Cu} / \mathrm{Mole} \mathrm{H}_{2} \mathrm{O}_{2}$ Formation Reference

Uricase.

1

$\mathrm{H}_{2} \mathrm{O}_{2}$

Galactose Oxidase

1

$\mathrm{H}_{2} \mathrm{O}_{2}$

Diamine oxidase

1

$\mathrm{H}_{2} \mathrm{O}_{2}$

$\mathrm{Cu}(\mathrm{II})$-Ascorbate

$\mathrm{H}_{2} \mathrm{O}_{2}$

$\mathrm{Cu}(\mathrm{II})-\mathrm{p}-\mathrm{Ph}$ nylenediamine

$\mathrm{H}_{2} \mathrm{O}_{2}$

$\mathrm{Cu}(\mathrm{II})-\mathrm{Uri}$ cate

$\mathrm{H}_{2} \mathrm{O}_{2}$

Monoamine Oxidase

$4 *$

$\mathrm{H}_{2} \mathrm{O}_{2}$

Tyrosinase (Mushroom)

4

$\mathrm{H}_{2} \mathrm{O}$

Laccase

4,6

$\mathrm{H}_{2} \mathrm{O}$

Dopamine- -Hydroxylase

$4-7$

$\mathrm{H}_{2} \mathrm{O}$

Ascorbate Oxidase

8

$\mathrm{H}_{2} \mathrm{O}$

Ceruloplasmin

8

$\mathrm{H}_{2} \mathrm{O}$

* Enzyme also contains Pyridoxal phosphate. 
TABLE VIII

MECHANISM OF THE TWO ELECTRON TRANSFER CU OXIDASES

Two Consecutive Electron Transfer with one $\mathrm{Cu}$ Atom per Catalyst Molecule and $\mathrm{H}_{2} \mathrm{O}_{2}$. Formation.

1. Removal of an Electron from Substrate:

$$
\mathrm{En}-\mathrm{Cu}{ }^{+2}+\mathrm{AH}_{2} \longrightarrow \mathrm{EnCu}^{+2}-\mathrm{AH}_{2} \longrightarrow \mathrm{EnCu}^{+1}+\mathrm{AH} \cdot+\mathrm{H}^{+}
$$

2. First Electron Transfers to oxygen:

$$
\mathrm{En}-\mathrm{Cu}^{+1}+\mathrm{O}_{2} \rightleftharpoons \mathrm{En}-\mathrm{Cu}^{+1}-\mathrm{O}_{2} \rightleftharpoons \mathrm{En}-\mathrm{Cu}^{+1} \rightarrow \mathrm{O}_{2}\left[\mathrm{En}-\mathrm{Cu}{ }^{+2}-\left(\mathrm{O}_{2}\right)^{-1}\right]
$$

3. Second Electron Transfer From Substrate:

$$
\begin{aligned}
& \mathrm{En}-\mathrm{Cu}^{+1} \rightarrow \mathrm{O}_{2}+\mathrm{AH} \cdot\left(\mathrm{AH}_{2}\right) \rightleftharpoons \mathrm{En}-\mathrm{Cu}^{+1} \longrightarrow \mathrm{O}_{2}^{-} \stackrel{2 \mathrm{H}^{+}}{\rightleftharpoons} \mathrm{En}-\mathrm{Cu}^{+2}+\mathrm{H}_{2} \mathrm{O}_{2} \\
& +\mathrm{A}(\mathrm{AH} \cdot)+\mathrm{H}^{+}
\end{aligned}
$$

4. Second Electron Transfer - From Second Catalyst Molecule:

$$
\begin{aligned}
& \mathrm{En}-\mathrm{Cu}^{+1} \longrightarrow \mathrm{O}_{2}+\mathrm{En}-\mathrm{Cu}^{+1} \rightleftharpoons \mathrm{En}-\mathrm{Cu}^{+1} \longrightarrow \mathrm{O}_{2} \hookleftarrow \mathrm{Cu}^{+1}-\mathrm{En} \\
& \stackrel{2 \mathrm{H}^{+}}{\Gamma} 2 \mathrm{En}-\mathrm{Cu}{ }^{+2}+\mathrm{H}_{2} \mathrm{O}_{2}
\end{aligned}
$$


TABLE IX

MECHANISM OF THE COPPER ELECTRON TRANSFER OXIDASES

(1) Removal of Four Electrons from Four (or less) Substrate Molecules (not necessarily simultaneous):

$\mathrm{En}-\mathrm{Cu}_{4}^{+2}+4 \underline{\mathrm{AH}}_{2} \rightleftharpoons \mathrm{En}-\mathrm{Cu}_{4}^{+1}+4 \underline{\mathrm{AH}} \cdot+4 \mathrm{H}^{+}$

(2) Transfer of Four Electrons to Oxygen:

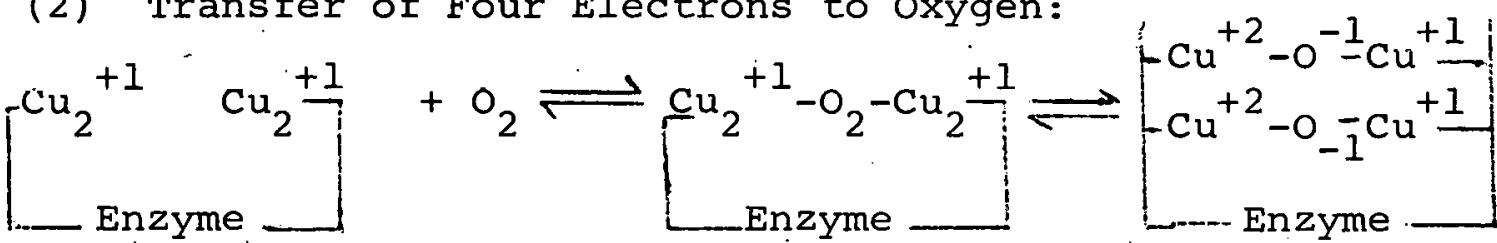

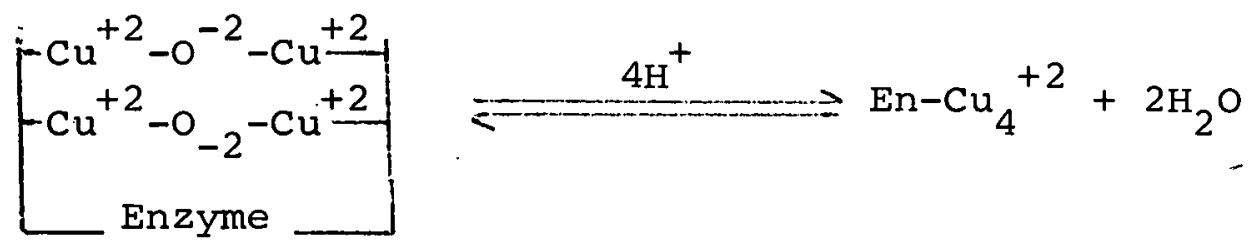

Possible Special Mechanism for Ceruloplasmin $\left(4 \mathrm{Cu}^{+1}, 4 \mathrm{Cu}^{+2}\right)$

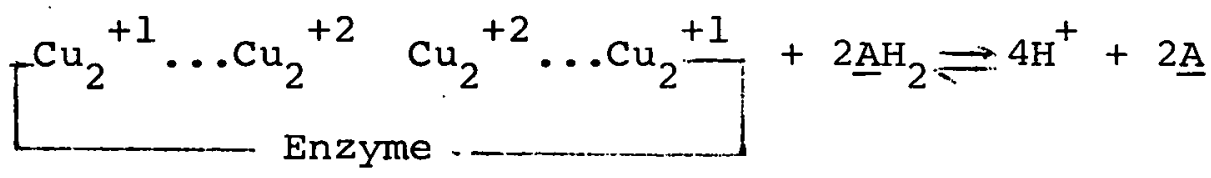

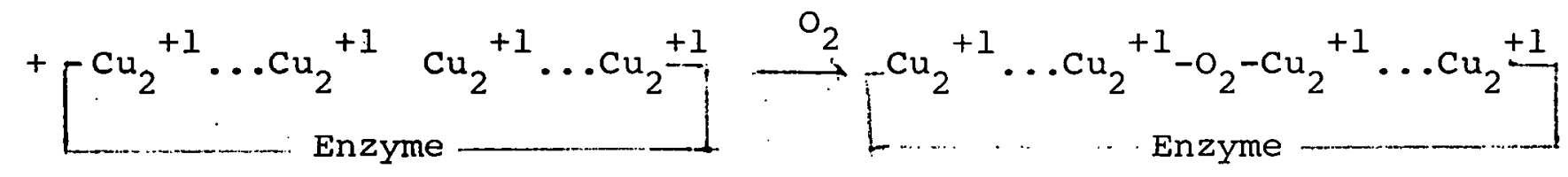

$\longrightarrow\left[\begin{array}{l}\mathrm{Cu}_{2}^{+1} \ldots \mathrm{Cu}_{2}{ }^{+2}-\mathrm{O}_{2}{ }^{-4}-\mathrm{Cu}_{2}{ }^{+2} \ldots \mathrm{Cu}_{2}+1 \\ \text { Enzyme }\end{array} \rightarrow \mathrm{Cu}_{2}^{+2} \ldots \mathrm{Cu}_{2}^{+1}-\mathrm{O}_{2}^{-4}-\mathrm{Cu}_{2}^{+1} \ldots \mathrm{Cu}_{2}+2\right.$

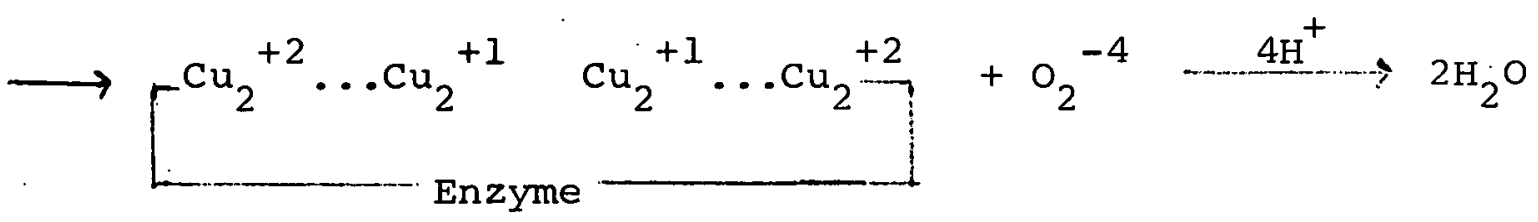


TABLE $\mathrm{X}$

COMPARISON OF THE CATALYSIS OF ASCORBATE OXIDATION BY CU(I), SQUASH ASCORBATE OXIDASE AND CERULOPLASMIN

PROPERTY

pH OPTIMUM.

MOLES $\mathrm{H}_{2} \mathrm{O}_{2}$ /MOLES

DEHYDROASCORB . 1

$\mathrm{K}_{\mathrm{m}}$ FOR ASCORBATE, $\mathrm{M}$

$\mathrm{K}_{\mathrm{m}}$ FOR $\mathrm{O}_{2}, \mathrm{M}$

ACTIVITY $/ \mathrm{Cu}$

150

$$
\frac{\mathrm{Cu}(\mathrm{II})}{7.5}
$$

$7 \times 10^{-3}$

0

0

$2 \times 10^{-4} 2.2 \times 10^{-4}$

$1.3 \times 10^{-5}$

$10^{5}$

12 
TABLE XI

SUMMARY OF DIFFERENCES BETWEEN CERULOPLASMIN- AND
CU (II)-CATALYZED OXIDATION OF ASCORBATE

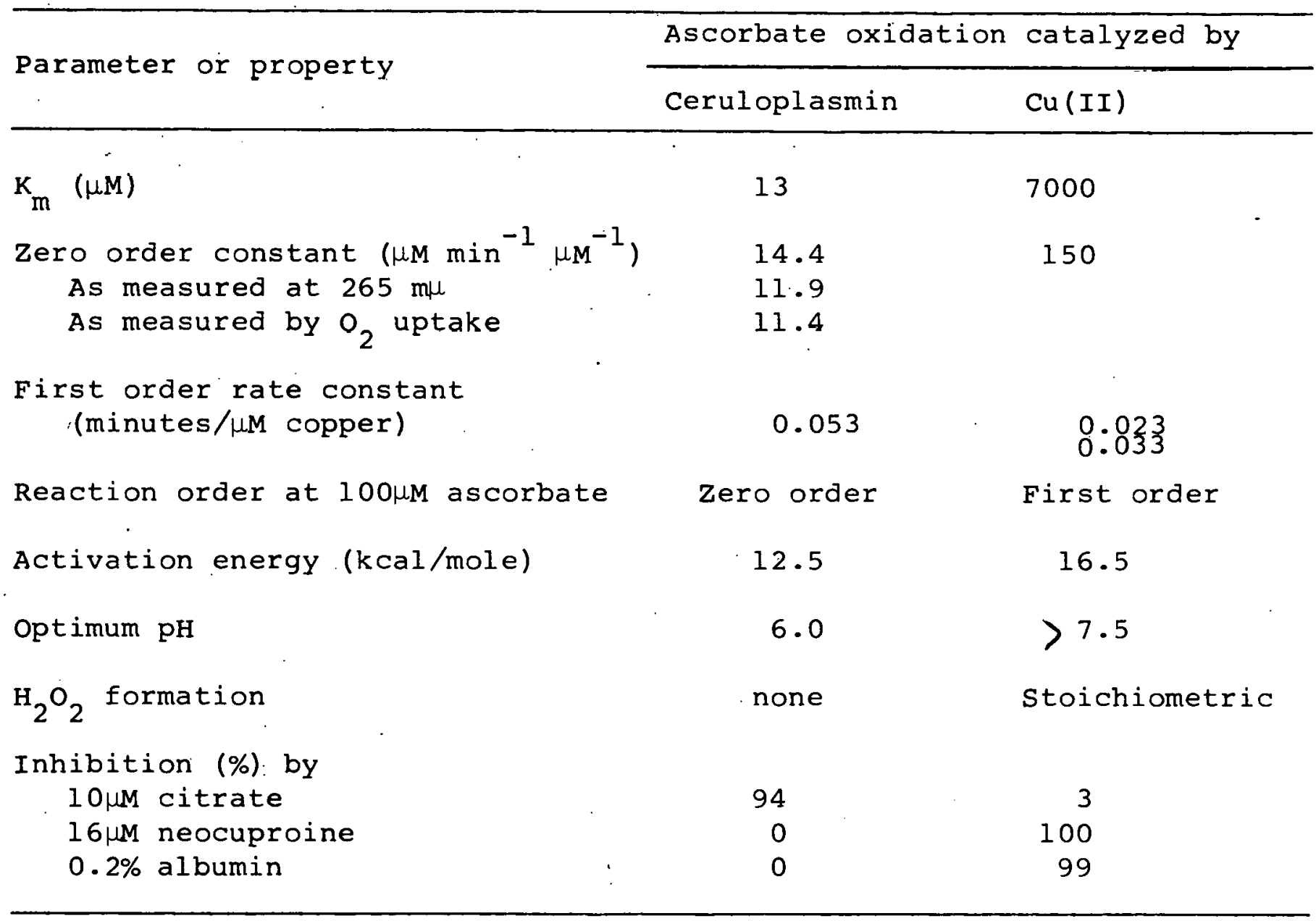

Kinetic parameters were obtained at $\mathrm{pH} 5.2$ and $30^{\circ}$ unless otherwise stated in the original paper, S. Osaki, J. McDermott and E. Frieden 28 . 
TABLE XII

EFFECTS OF CITRATE, NEOCUPROINE AND SERUM ALBUMIN ON ASCORBATE OXIDATION BY CERULOPLASMIN AND CU(II)

\begin{tabular}{|c|c|c|c|c|}
\hline \multirow{3}{*}{ Inhibitor } & \multirow{3}{*}{ Concentration } & \multicolumn{3}{|c|}{$\begin{array}{l}\text { Inhibition of ascorbate } \\
\text { oxidation by }\end{array}$} \\
\hline & & \multicolumn{2}{|c|}{ Ceruloplasmin } & $\mathrm{Cu}(\mathrm{II})$ \\
\hline & & $\mathrm{pH} \quad 5.2$ & $\mathrm{pH} \quad 7.0$ & $\mathrm{pH} 5.2$ \\
\hline & $\mu \mathrm{m}$ & $\%$ & $\%$ & $\%$ \\
\hline \multirow[t]{11}{*}{ Citrate } & 0.2 & 42 & & 0 \\
\hline & 0.33 & & 40 & \\
\hline & 0.5 & 62 & & 0 \\
\hline & 1.67 & & 53 & \\
\hline & 2.0 & 81 & & 0 \\
\hline & 5.0 & 88 & & 0 \\
\hline & 10.0 & 94 & & 0 \\
\hline & 16.7 & & 87 & \\
\hline & 84.0 & & 97 & . \\
\hline & $100 \cdot 0^{a}$ & 95 & & 18 \\
\hline & $\mu \mathrm{m}$ & & & \\
\hline \multirow[t]{4}{*}{ Neocuproine } & 1.6 & 0 & & 37 \\
\hline & 2.3 & 0 & & 60 \\
\hline & 3.3 & 0 & & 100 \\
\hline & 16.0 & 0 & & 100 \\
\hline & per cent & & & \\
\hline Bovine serum & 0.01 & 0 & & 12 \\
\hline \multirow[t]{4}{*}{ albumin } & 0.03 & 0 & & 40 \\
\hline & 0.05 & 0 & & 60 \\
\hline & 0.10 & 0 & & 80 \\
\hline & 0.20 & 0 & & 99 \\
\hline
\end{tabular}

All experiments were carried out at $\mathrm{pH} 5.2$ and $30^{\circ}$ unless otherwise stated. In the citrate inhibition experiments $38 \mu \mathrm{M}$ ascorbate, and in the neocuproine and albumin inhibition experiments $36 \mu \mathrm{M}$ ascorbate were used. Citrate and neocuproine concentrations are micromolar; bovine serum albumin concentration is given as per cent. Ceruloplasmin concentration was $1.5 \times 10^{-7} \mathrm{M}$ except in citrate inhibition, in which $1.6 \times 10^{-7}$ and $2.7 \times 10^{-7} \mathrm{M}$ ceruloplasmin were used at $\mathrm{pH} 5.2$ and 7.0 , respectively. $\mathrm{Cu}($ II) concentration was $1.6 \times 10^{-6} \mathrm{M}$.

acorresponds to the normal range of citrate concentration in human plasma. Data from osaki et al. 28 
TABLE XIII

KINETIC PARAMETERS FOR CERULOPLASMIN IN $0.1 \mathrm{M}$ TRIETHYLAMINE-ACETIC ACID BUFFER ( $\mathrm{pH} 5.5)$ at $17^{\circ} \mathrm{C}$, DETERMINED BY ESR MEASUREMENTS

\begin{tabular}{|c|c|c|c|c|c|c|c|}
\hline Substrate & $\begin{array}{l}t / 2 \\
(\min )\end{array}$ & $c_{s} / c_{0}$ & $\begin{array}{c}\mathrm{k}_{1} \\
\left(\mathrm{~min}^{-1}\right)\end{array}$ & $\left.\mathrm{q}^{\prime} \mathrm{o}_{2}{ }^{1}\right)$ & $\begin{array}{c}t \\
(\min )\end{array}$ & $\begin{array}{c}q^{\prime \prime} o_{2} \\
(\min -1)\end{array}$ & $\begin{array}{c}\mathrm{k}_{2} \\
(\mathrm{~min}-1)\end{array}$ \\
\hline $\mathrm{pPD}$ & 0.015 & 0.20 & 37 & 0.92 & 0.4 & 0.9 & 9.2 \\
\hline pyrogaliol & 0.065 & 0.47 & 5.6 & 0.34 & 1.4 & 0.27 & 5.0 \\
\hline Catechol & 0.08 & $\therefore 0.48$ & 4.5 & $\ldots 0.27$ & 3 & 0.12 & 4.2 \\
\hline Quinol & 0.4 & 0.80 & 0.35 & 0.035 & 10 & 0.036 & 1.4 \\
\hline $\begin{array}{c}\text { Hydroxyl- } \\
\text { amine }\end{array}$ & - & $>0.7$ & - & - & $>20$ & - & - \\
\hline
\end{tabular}

Initial concentrations: total copper $\left(c_{\text {tot }}\right),-8 \cdot 10^{-4} \mathrm{M} ; \mathrm{Cu}^{2+}\left(\mathrm{c}_{0}\right)$, $4 \cdot 10^{-4} \mathrm{M} ; \mathrm{O}_{2}\left(\mu_{0}\right), 2.9 \cdot 10^{-4} \mathrm{M} ;$ and substrates, $5 \cdot 10^{-3} \mathrm{M}$. Data from Broman et al. ${ }^{11}$ 


\section{LEGENDS TO FIGURES}

1. Relative rates of oxygenation of two hemocyanins at $20^{\circ}$ under approximate. "physiological" conditions. The oxygenation was measured by blue color formation using Hartridge-Roughton rapid flow techniques. Data adapted from Millikan.7

2. The dependence of oxygen uptake on the partial pressure of oxygen. The relative rate on the vertical axis is the per cent of the maximum oxygen consumption. Identifications are as follows: A, yeast cytochrome oxidase data of winzler ${ }^{55}$ $B$, freshly cut $0.5 \mathrm{~mm}$ potato disks at $15^{\circ}$ (indistinguishable from A): C, disks kept 1 day at $25^{\circ}$, measured at $15^{\circ} ; \mathrm{D}$, plant ascorbate oxidase measured at $25^{\circ}$. Data adapted from Thimann et al. 13

3. Comparative effects of air and $100 \%$ oxygen on gelatin protected and unprotected plant ascorbate oxidase. Each experiment included .010 M phosphate buffer, $\mathrm{pH} 7.2$, .020 M ascorbate, $1.0 \mathrm{mg}$ per $\mathrm{ml}$ gelatin and 5.0 units ascorbate oxidase at $30^{\circ}$. Data from Frieden and Maggiolo. 14

4a. The determination of the $\mathrm{K}_{\mathrm{m}}$ of ceruloplasmin with respect to oxygen. The velocity of oxygen uptake in the oxidation of ascorbate in $0.2 \mathrm{M}$ acetate buffer at pH 5.2 by $0.3 \mu \mathrm{M}$ ceruloplasmin is measured polarographically at various concentrations of oxygen at $30^{\circ} \mathrm{C}$. Ascorbate concentration was kept high enough $(170 \mu \mathrm{M})$ to get zero order rate with respect to the substrate. Neocuproine was added up to $15 \mu \mathrm{M}$ to prevent effect by any unforeseen inorganic copper ion contamination. 
4b. The determination of the $\mathrm{K}_{\mathrm{m}}$ of tyrosinase with respect to oxygen. The velocity of tyrosine oxidation measured by absorbance change at $475 \mathrm{~m} \mu, v$, is plotted against $v / \mathrm{s}$ or $\mathrm{s}$ at various oxygen concentrations between 2 and $200 \mu \mathrm{M}$. The reaction mixture containing $3 \times 10^{-4} \mathrm{M}$ tyrosine in $0.022 \mathrm{M}$ phosphate buffer is equilibrated to desirable oxygen concentration by bubbling the gas mixture through the solution in a cuvette at a rate of $20 \mathrm{ml} / \mathrm{min}$ at $30^{\circ} \mathrm{C}$. After 20 minutes of equilibration time, $20 \mu l$ of tyrosinase was added to the reaction mixture.

5. Postulated structure of the blue copper chelate formed by one copper ion, two molecules of oxalyldihydrazide, four molecules of acetaldehyde.

6a. Reduction of $\mathrm{Cu}(\mathrm{II})$ to $\mathrm{Cu}(\mathrm{I})$ by sulfhydryl compounds in the presence of neocuproine.

6b. Quantitative reaction of cysteine and glutathione by the reduction of $\mathrm{Cu}(\mathrm{II})$ in the presence of neocuproine. Each $4.0 \mathrm{ml}$ of reaction mixture contained $5.0 \times 10^{-5} \mathrm{M}$ cupric chloride, $2.5 \times 10^{-5} \mathrm{M}$ neocuproine, $0.01 \mathrm{M}$ phosphate buffer, $\mathrm{pH} 7.0$, and the indicated amount of cysteine or glutathione. The optical density at $455 \mathrm{m \mu}$ was measured at $25^{\circ} \mathrm{C}$. Data from Frieden. 24

7. Electron configuration of oxy-hemocyanin based on molecular orbital theory. Two arrows at spin indicate spin coupling of the unpaired electron of each copper atom. The filled and open circles indicate electrons and holes (vacancies), respectively.

8. Postulated mechanism of action of uricase as proposed by Mahler. 29 
9. The effect of varying $C u(I I)$ on the rate of oxidation of $.020 \mathrm{M}$ ascorbate in .010 M phosphate buffer, $\mathrm{pH} 7.1$ at $30^{\circ}$. The Warburg method was used to measure oxygen uptake with air as the gas phase. Wahlborg and Frieden. 56

10. Upper fig.: Proposed mechanism of hydroxylation and oxidation by tyrosinase. Lower fig.: Proposed intermediate in the $\mathrm{Cu}(\mathrm{II})-\mathrm{H}_{2} \mathrm{O}_{2}$ catalyzed ortho hydroxylation of phenols and aromatic amines.

11. Kinetic difference between catalysis of ascorbate oxidation by ceruloplasmin and $\mathrm{Cu}(\mathrm{II})$ in $.02 \mathrm{M}$ acetate buffer $\mathrm{pH} 5.2$ at $30^{\circ}$. The rate of ascorbate oxidation as the absorbance change at $265 \mathrm{mll}$ per minute is plotted against substrate concentration. Ceruloplasmin $\left(1.95 \times 10^{-7} \mathrm{M}\right)$ or $\mathrm{Cu}(\mathrm{II})\left(1.6 \times 10^{-6} \mathrm{M}\right)$ was used with or without $0.15 \%$ bovine serum albumin as indicated. From Osaki et al. 28

12. Experimental (solid lines) and calculated (dashed lines) ESR absorption of $\mathrm{Cu}^{+2}$ and of free radical in experiments with ceruloplasmin and pPD. The calculated curves are obtained with $\mathrm{k}^{\prime}{ }_{1}=7.4 \times 10^{3} \mathrm{M}^{-1} \times \mathrm{min}^{-1}, \mathrm{k}^{\prime}{ }_{2} \mathrm{~h}=71 \mathrm{M}^{-1 / 4} \mathrm{xmin}^{-1}$ and $\mathrm{k}_{\mathrm{d}}=1.25 \times 10^{4} \mathrm{M}^{-1} \times \mathrm{min}^{-1}$. The upper part of the figure shows results obtained with solutions equilibrated with air; the lower part shows results when pure $\mathrm{O}_{2}$ had been bubbled through the substrate solution. From Broman et al. ${ }^{11}$ 


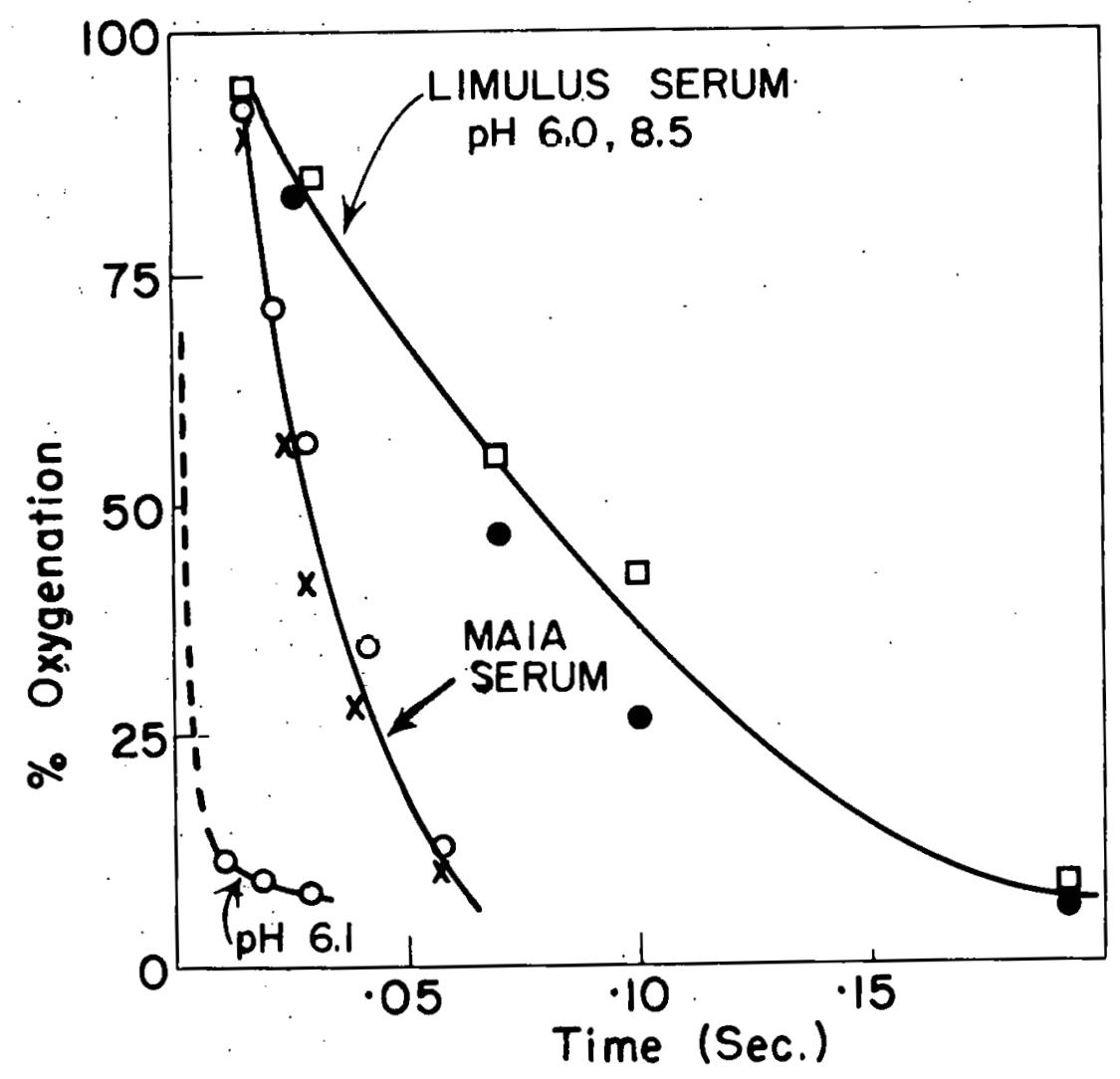

FIGURE 1 


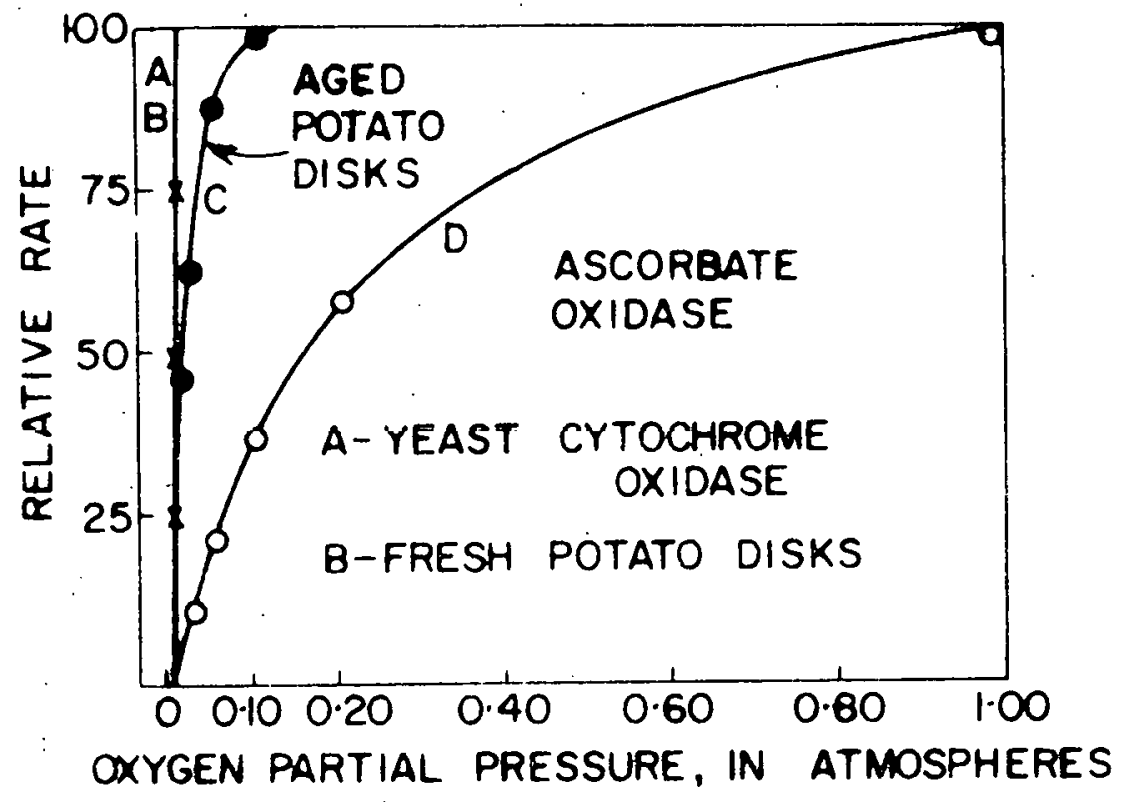

Fig. 2 


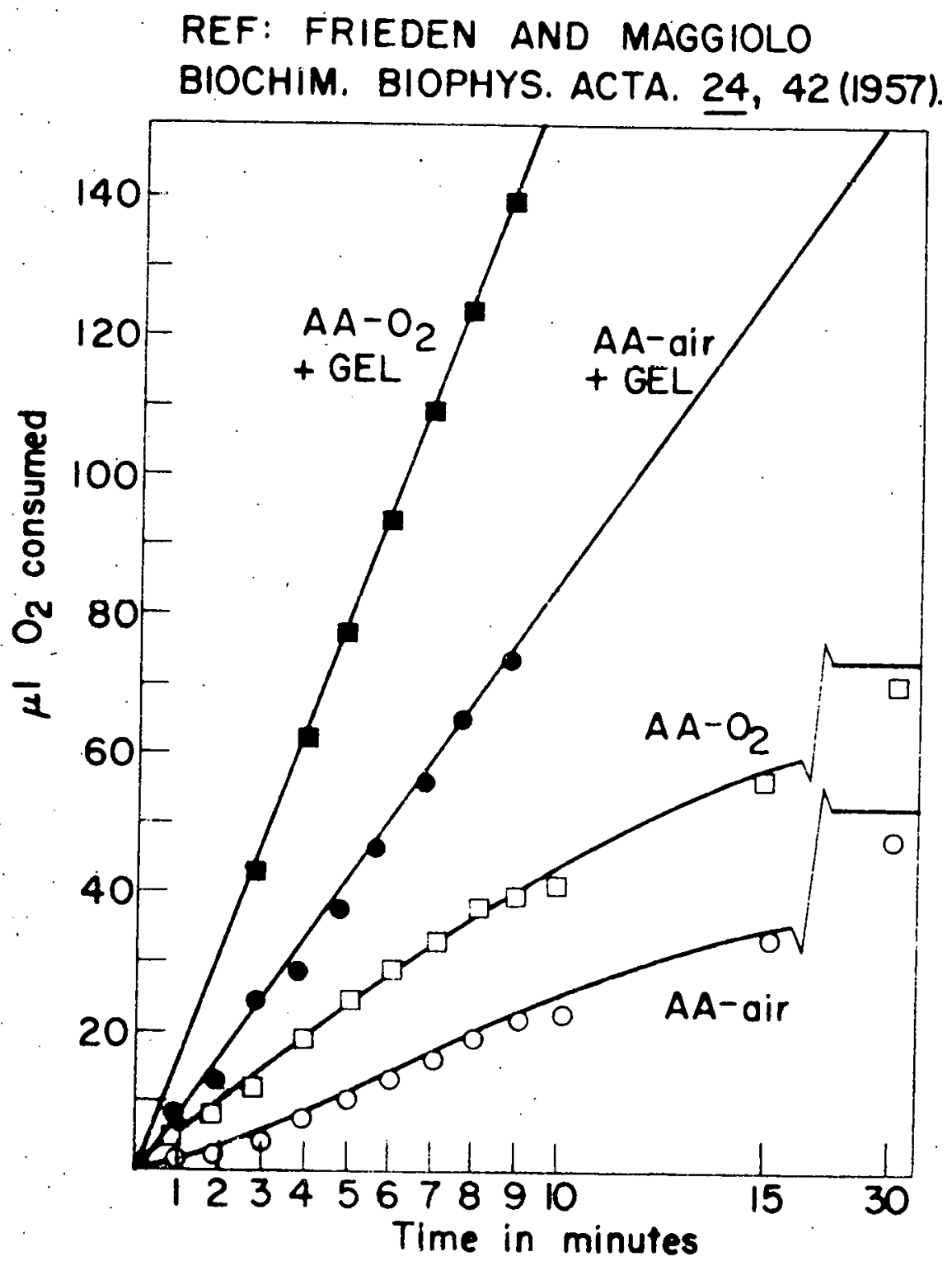

Fig. 3 
Effect of $\mathrm{O}_{2}$ on CERULOPLASMIN ACTIVITY

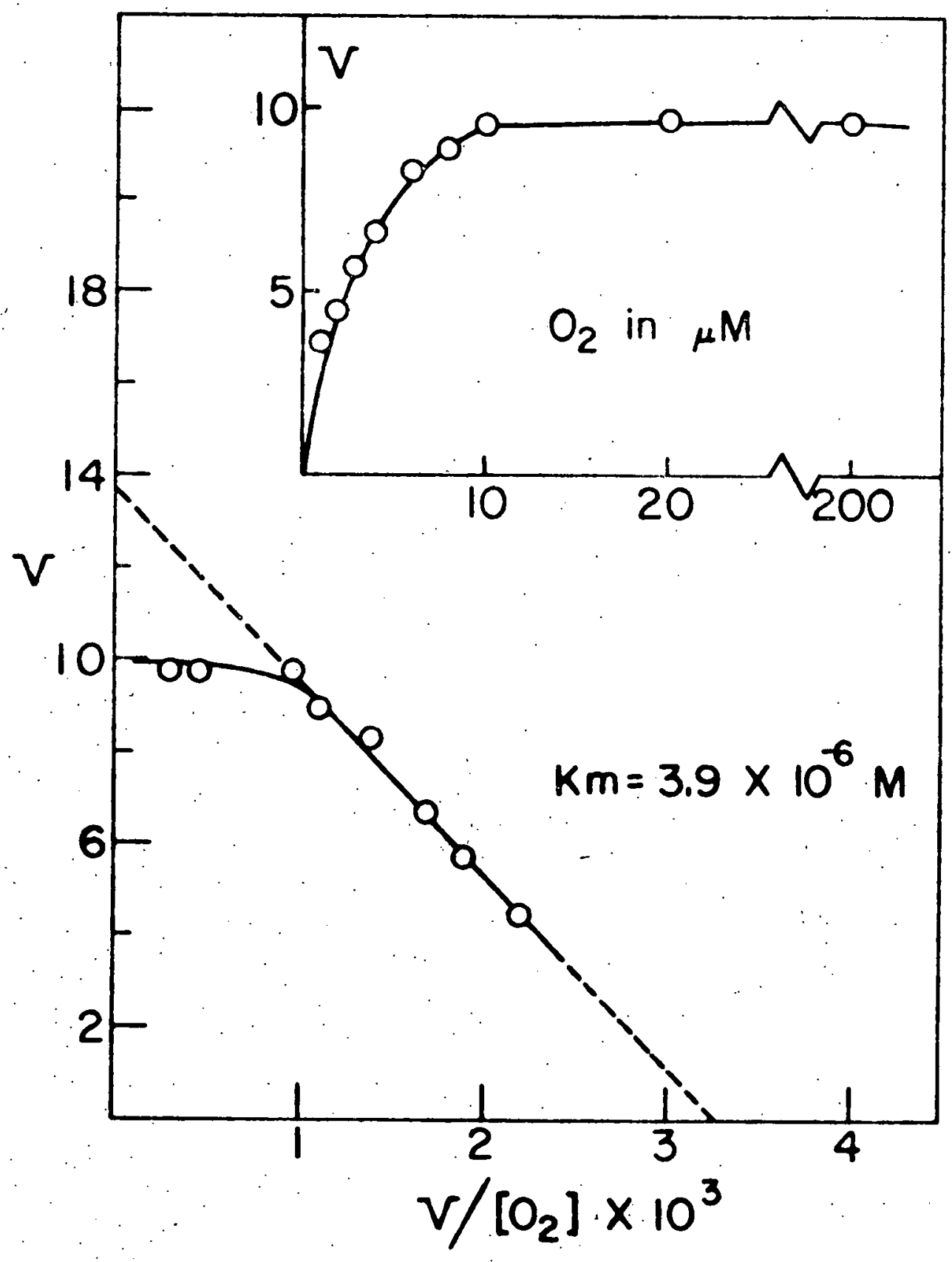

Fig. $4 a$

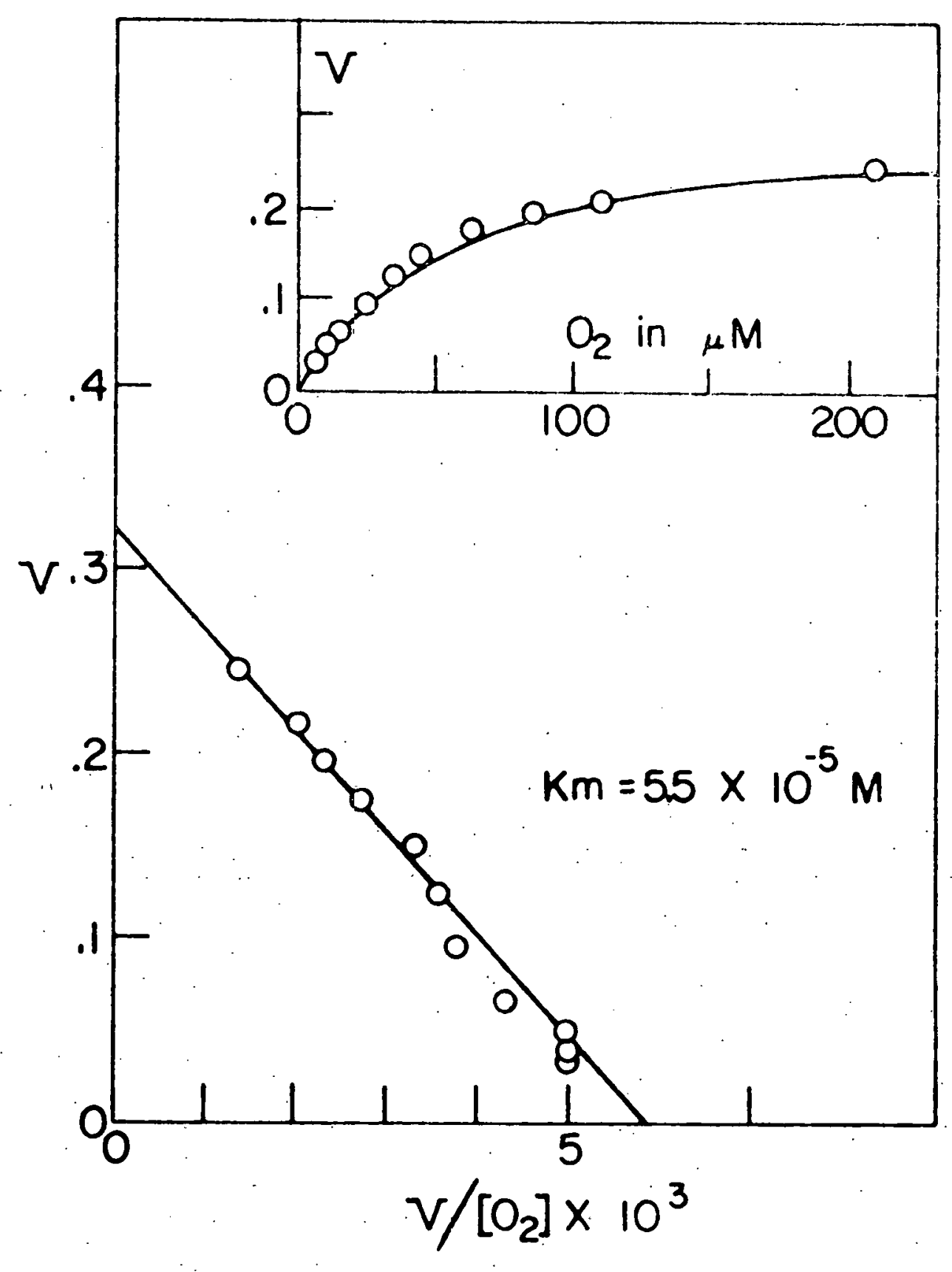




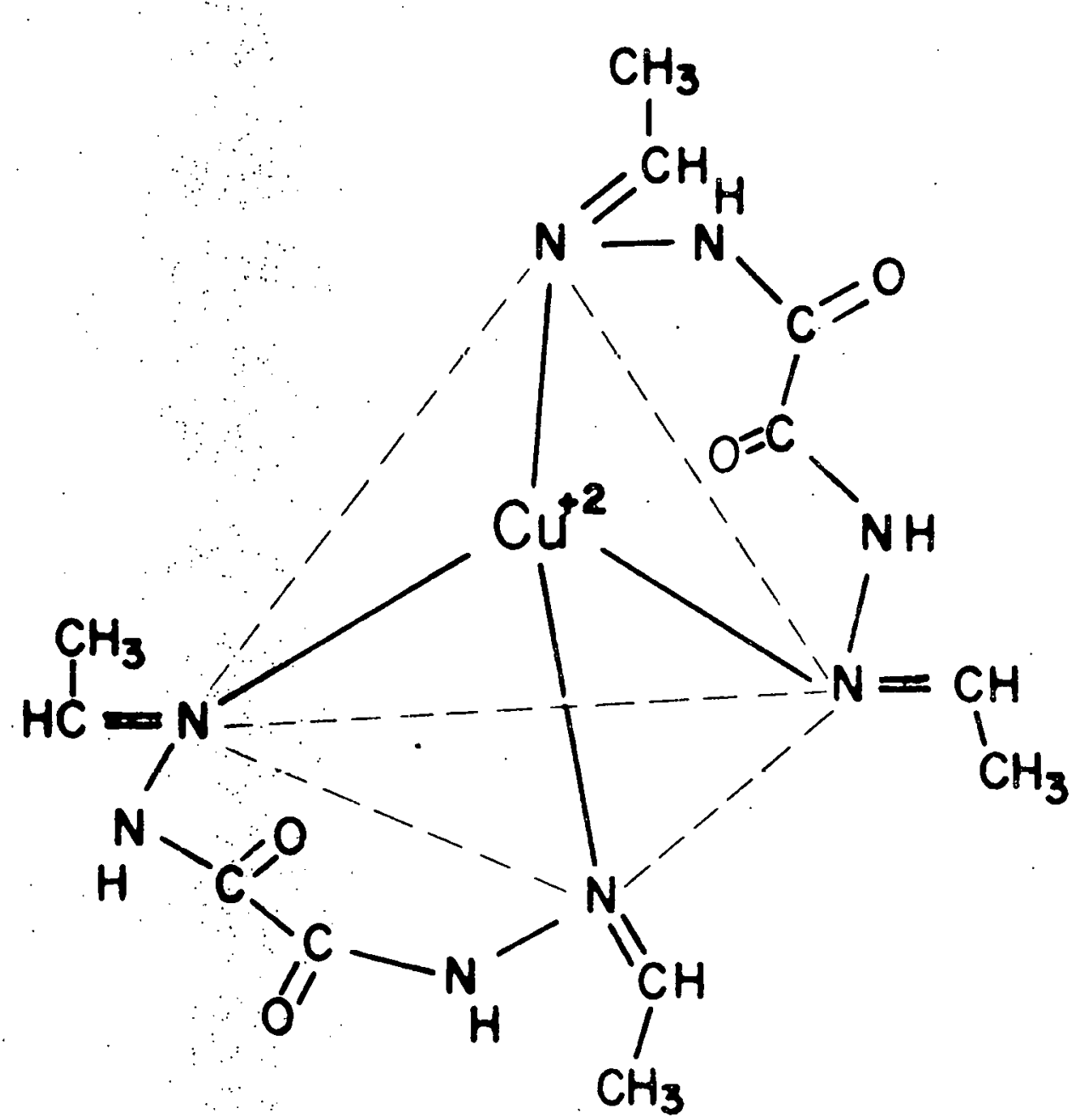

Fig. 5 


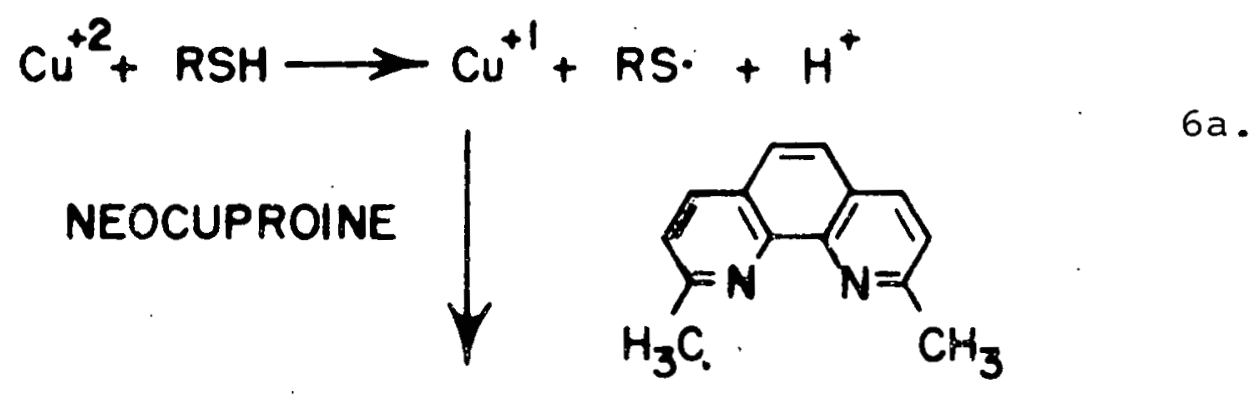

\section{$\mathrm{Cu}^{+1}$-NEOCUPROINE COMPLEX \\ (YELLOW)}

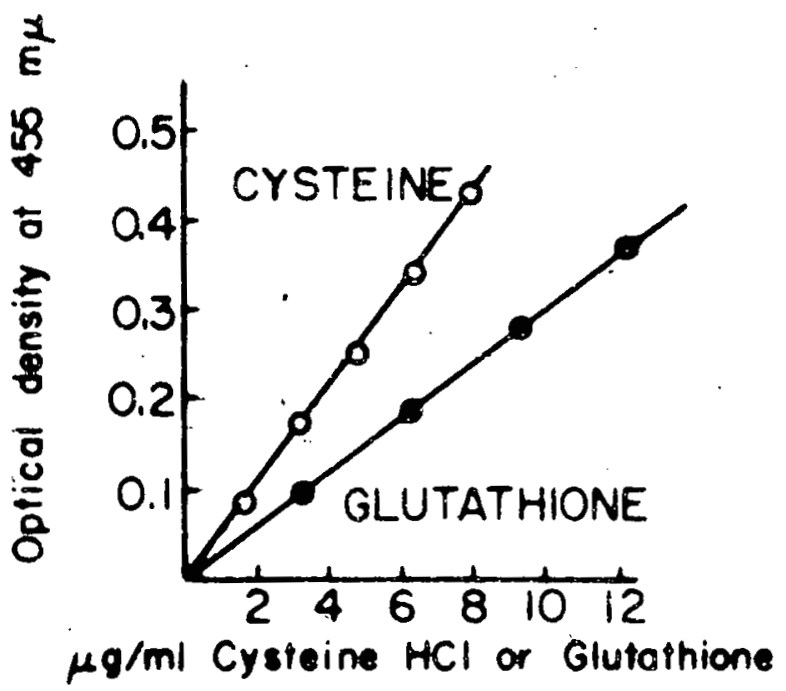

$6 \mathrm{~b}$.

Fig. 6 


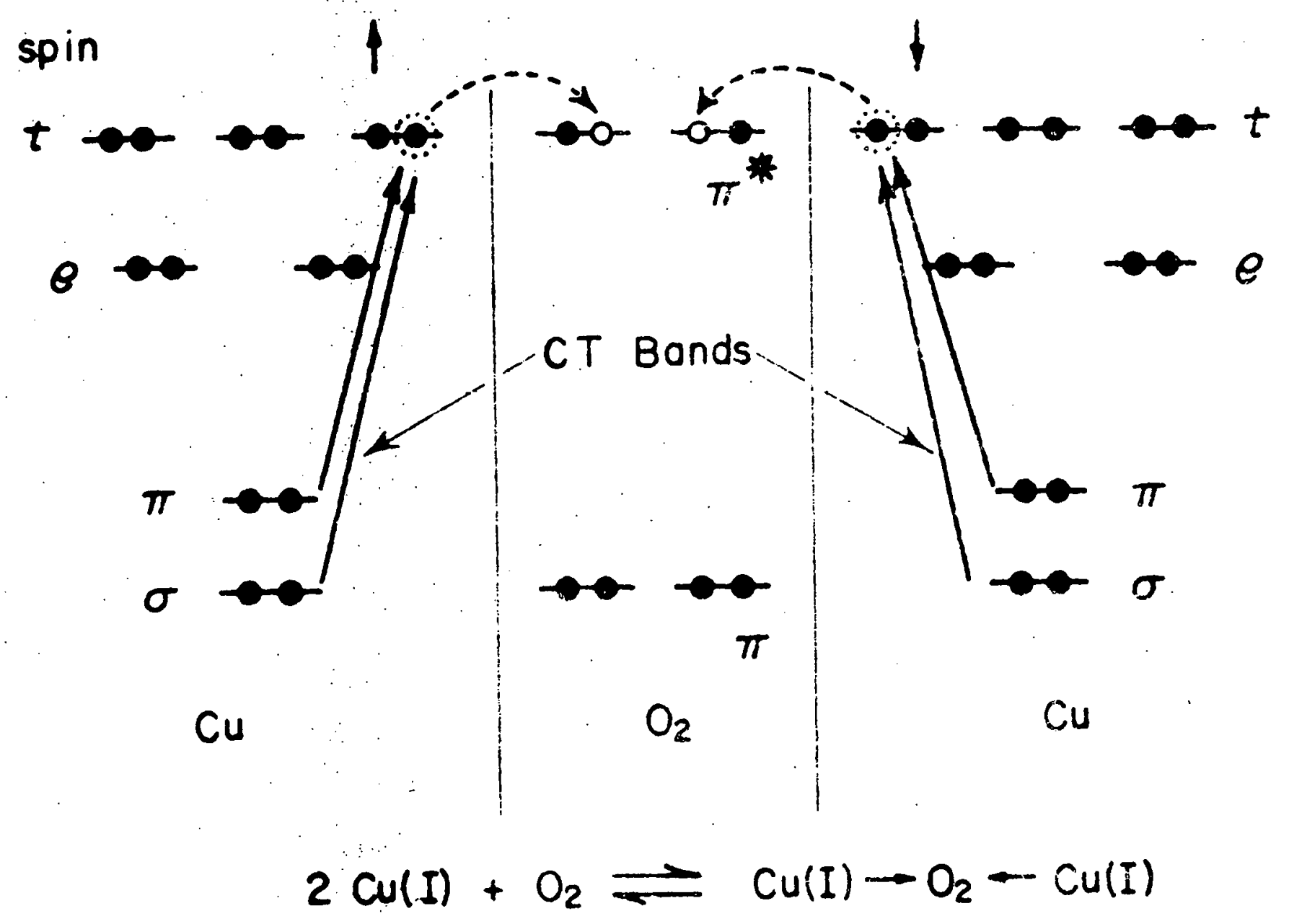

Fi8.7. Fneden 

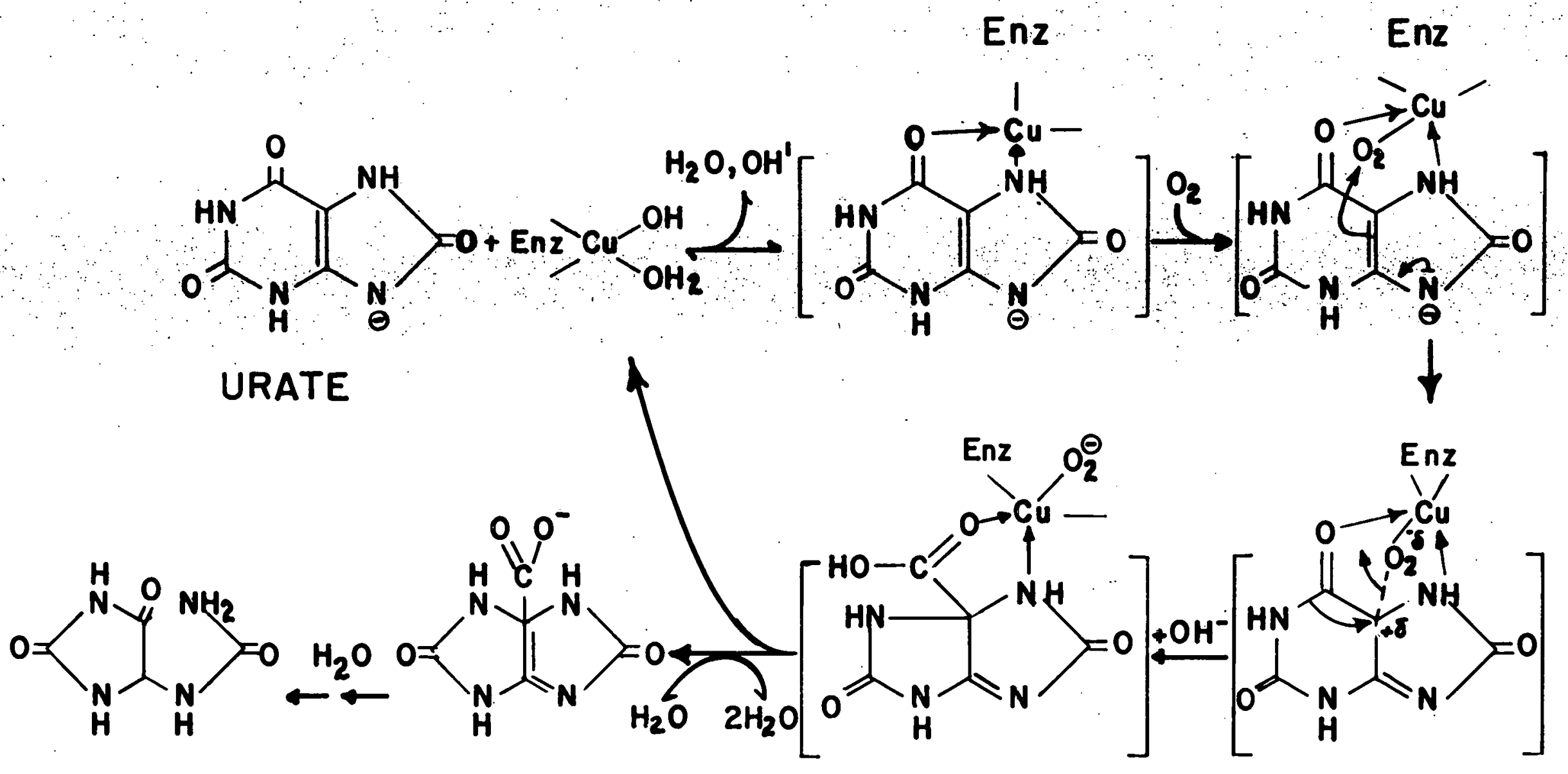

ALLANTOIN 


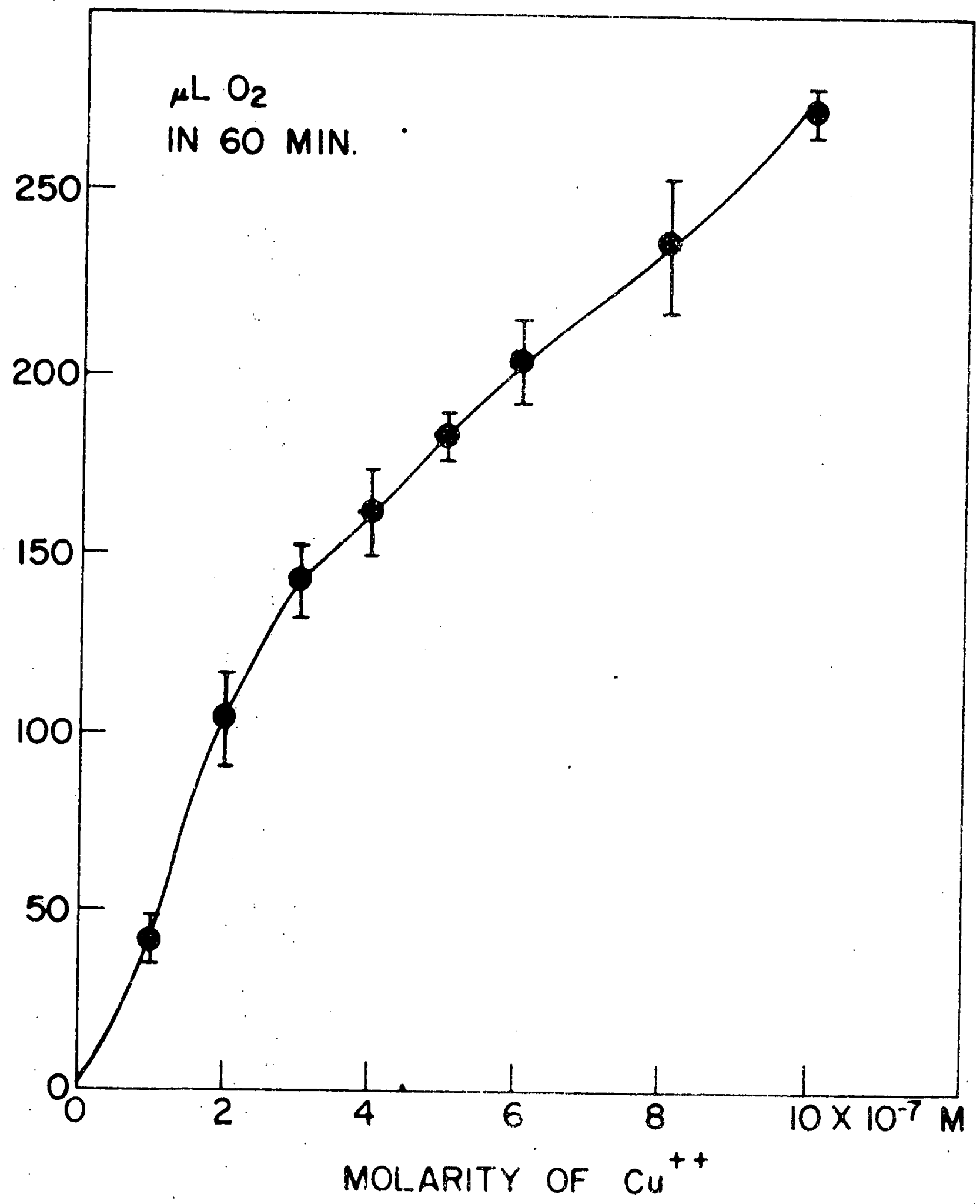

Fig. 9 
MECHANISM OF ACTION OF TYROSINASE

HYDROXYLATION:

$\mathrm{EnCu}_{2}^{+1}+\mathrm{O}_{2} \rightarrow \mathrm{EnCu}_{2}^{+1}-\mathrm{O}_{2} \rightarrow \mathrm{EnCu}_{2}^{+2}-\left(\mathrm{O}_{2}\right)^{-2} \mathrm{H}^{+} \mathrm{EnCu}_{2}^{+2}-(\mathrm{OOH})^{-1}$

$\mathrm{EnCu}_{2}^{+2}(\mathrm{OOH})^{-1}+\underbrace{\mathrm{OH}}_{\mathrm{R}} \rightarrow \mathrm{OHH}_{\mathrm{OH}}^{\mathrm{OH}}+\mathrm{H}+\mathrm{EnCu}_{2}^{+2}-(\mathrm{O})^{-2}$

\section{OXIDATION:}

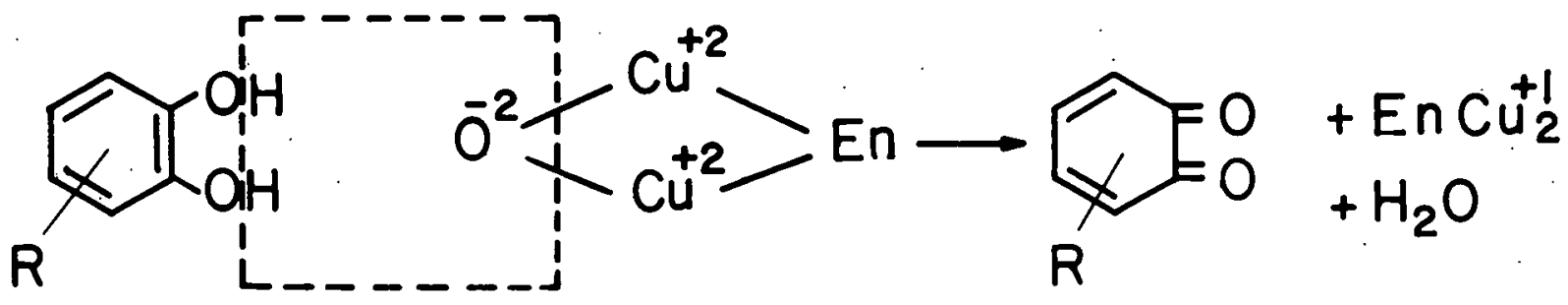

PROPOSED INTERMEDIATE

IN $\mathrm{Cu}^{+2}-\mathrm{H}_{2} \mathrm{O}_{2}$ CATALYZED

ORTHO HYDROXYLATION

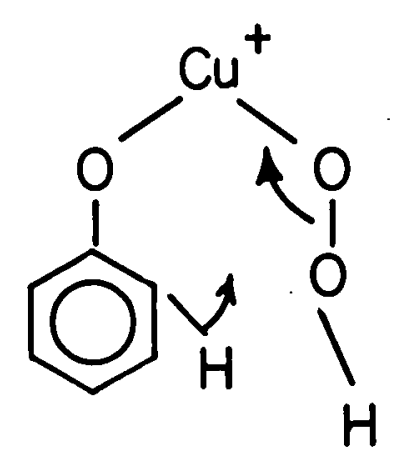

Fig. 10 


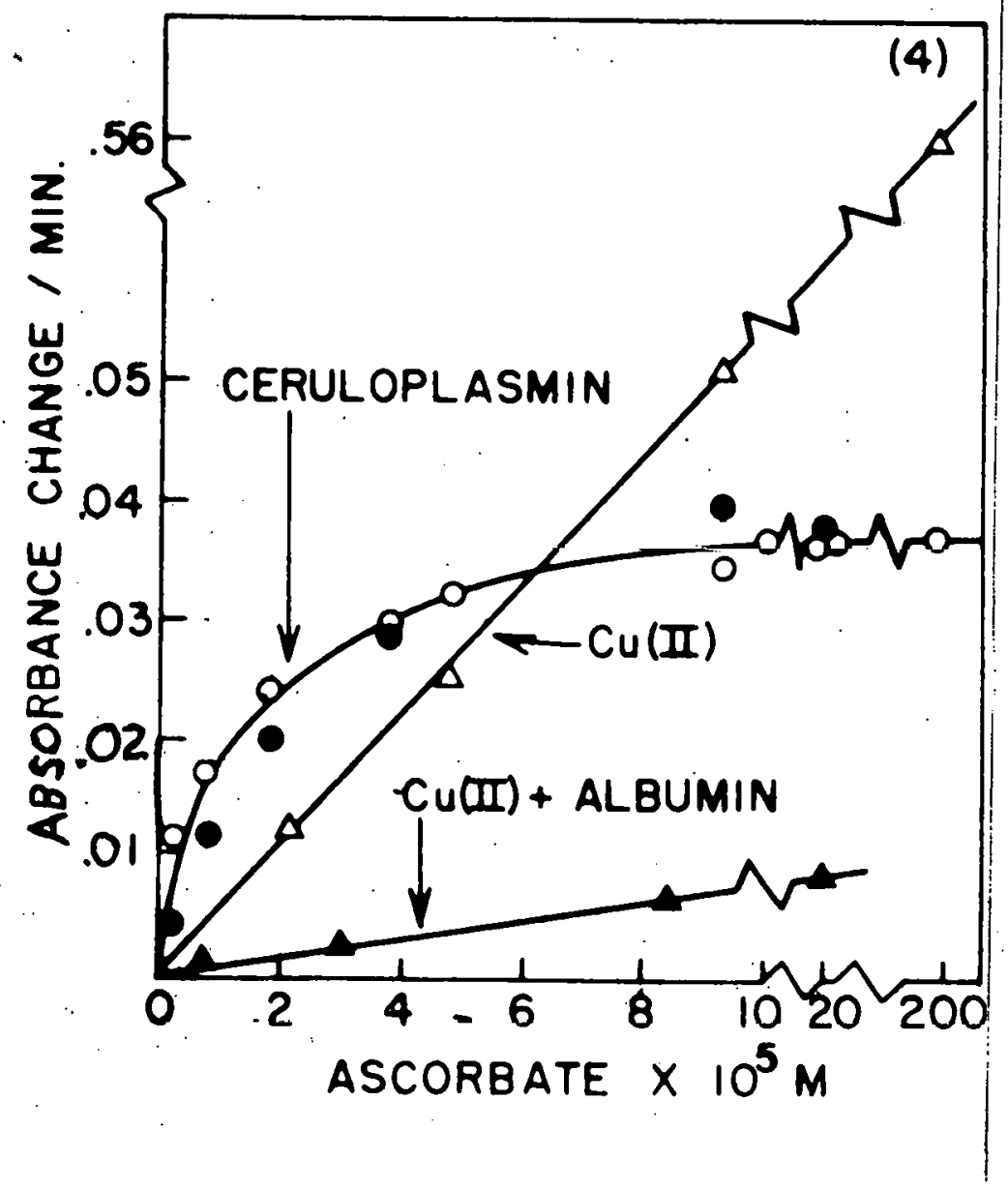

Fig. II 


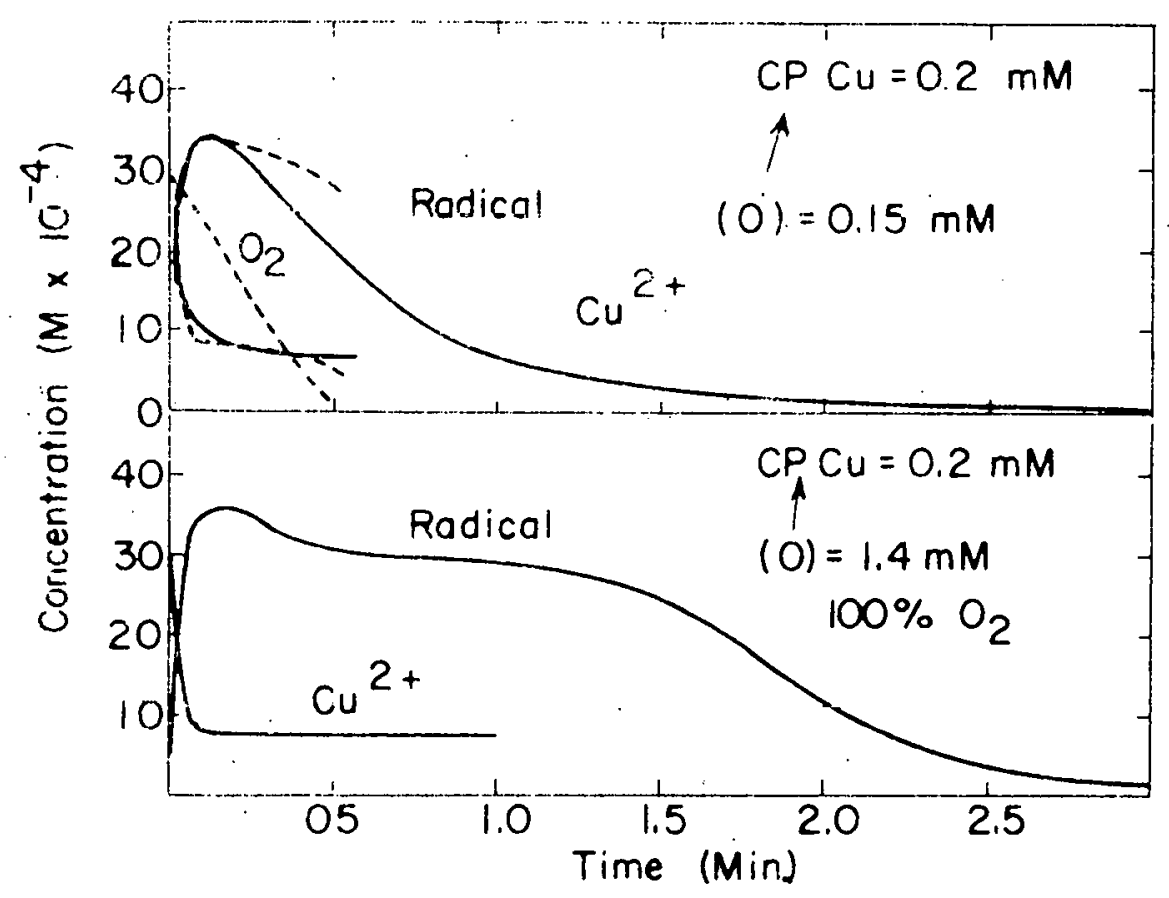

Fig. 12 